Article

\title{
The $\mathrm{K}_{2} \mathrm{CO}_{3}-\mathrm{CaCO}_{3}-\mathrm{MgCO}_{3}$ System at $6 \mathrm{GPa}$ Implications for Diamond Forming Carbonatitic Melts
}

\author{
Anton V. Arefiev ${ }^{1,2}$, Anton Shatskiy 1,2, , Ivan V. Podborodnikov ${ }^{1,2}$ and Konstantin D. Litasov ${ }^{1,2}$ \\ 1 Department of Geology and Geophysics, Novosibirsk State University, Novosibirsk 630090, Russia; \\ arefievanton@igm.nsc.ru (A.V.A.); podborodnikov@igm.nsc.ru (I.V.P.); klitasov@igm.nsc.ru (K.D.L.) \\ 2 Sobolev Institute of Geology and Mineralogy, Siberian Branch Russian Academy of Science, \\ Novosibirsk 630090, Russia \\ * Correspondence: shatskiy@igm.nsc.ru; Tel.: +7-(383)-330-75-01
}

Received: 24 August 2019; Accepted: 13 September 2019; Published: 16 September 2019

\begin{abstract}
Carbonate micro inclusions with abnormally high $\mathrm{K}_{2} \mathrm{O}$ appear in diamonds worldwide. However, the precise determination of their chemical and phase compositions is complicated due to their sub-micron size. The $\mathrm{K}_{2} \mathrm{CO}_{3}-\mathrm{CaCO}_{3}-\mathrm{MgCO}_{3}$ is the simplest system that can be used as a basis for the reconstruction of the phase composition and $P-T$ conditions of the origin of the K-rich carbonatitic inclusions in diamonds. In this regard, this paper is concerned with the subsolidus and melting phase relations in the $\mathrm{K}_{2} \mathrm{CO}_{3}-\mathrm{CaCO}_{3}-\mathrm{MgCO}_{3}$ system established in Kawai-type multianvil experiments at $6 \mathrm{GPa}$ and $900-1300{ }^{\circ} \mathrm{C}$. At $900{ }^{\circ} \mathrm{C}$, the system has three intermediate compounds $\mathrm{K}_{2} \mathrm{Ca}_{3}\left(\mathrm{CO}_{3}\right)_{4}$ (Ca\# $\geq 97), \mathrm{K}_{2} \mathrm{Ca}\left(\mathrm{CO}_{3}\right)_{2}(\mathrm{Ca} \# \geq 58)$, and $\mathrm{K}_{2} \mathrm{Mg}\left(\mathrm{CO}_{3}\right)_{2}(\mathrm{Ca \#} \leq 10)$, where $\mathrm{Ca \#}=100 \mathrm{Ca} /(\mathrm{Ca}+\mathrm{Mg})$. Miscibility gap between $\mathrm{K}_{2} \mathrm{Ca}\left(\mathrm{CO}_{3}\right)_{2}$ and $\mathrm{K}_{2} \mathrm{Mg}\left(\mathrm{CO}_{3}\right)_{2}$ suggest that their crystal structures differ at $6 \mathrm{GPa}$. Mg-bearing $\mathrm{K}_{2} \mathrm{Ca}\left(\mathrm{CO}_{3}\right)_{2}$ (Ca\# $\leq 28$ ) disappear above $1000{ }^{\circ} \mathrm{C}$ to produce $\mathrm{K}_{2} \mathrm{Ca}_{3}\left(\mathrm{CO}_{3}\right)_{4}+\mathrm{K}_{8} \mathrm{Ca}_{3}\left(\mathrm{CO}_{3}\right)_{7}$ $+\mathrm{K}_{2} \mathrm{Mg}\left(\mathrm{CO}_{3}\right)_{2}$. The system has two eutectics between 1000 and $1100{ }^{\circ} \mathrm{C}$ controlled by the following melting reactions: $\mathrm{K}_{2} \mathrm{Ca}_{3}\left(\mathrm{CO}_{3}\right)_{4}+\mathrm{K}_{8} \mathrm{Ca}_{3}\left(\mathrm{CO}_{3}\right)_{7}+\mathrm{K}_{2} \mathrm{Mg}\left(\mathrm{CO}_{3}\right)_{2} \rightarrow\left[40 \mathrm{~K}_{2} \mathrm{CO}_{3} \cdot 60\left(\mathrm{Ca}_{0.70} \mathrm{Mg}_{0.30}\right) \mathrm{CO}_{3}\right]$ (1st eutectic melt) and $\mathrm{K}_{8} \mathrm{Ca}_{3}\left(\mathrm{CO}_{3}\right)_{7}+\mathrm{K}_{2} \mathrm{CO}_{3}+\mathrm{K}_{2} \mathrm{Mg}\left(\mathrm{CO}_{3}\right)_{2} \rightarrow\left[62 \mathrm{~K}_{2} \mathrm{CO}_{3} \cdot 38\left(\mathrm{Ca}_{0.73} \mathrm{Mg}_{0.27}\right) \mathrm{CO}_{3}\right]$ (2nd eutectic melt). The projection of the $\mathrm{K}_{2} \mathrm{CO}_{3}-\mathrm{CaCO}_{3}-\mathrm{MgCO}_{3}$ liquidus surface is divided into the eight primary crystallization fields for magnesite, aragonite, dolomite, Ca-dolomite, $\mathrm{K}_{2} \mathrm{Ca}_{3}\left(\mathrm{CO}_{3}\right)_{4}$, $\mathrm{K}_{8} \mathrm{Ca}_{3}\left(\mathrm{CO}_{3}\right)_{7}, \mathrm{~K}_{2} \mathrm{Mg}\left(\mathrm{CO}_{3}\right)_{2}$, and $\mathrm{K}_{2} \mathrm{CO}_{3}$. The temperature increase is accompanied by the sequential disappearance of crystalline phases in the following sequence: $\mathrm{K}_{8} \mathrm{Ca}_{3}\left(\mathrm{CO}_{3}\right)_{7}\left(1220^{\circ} \mathrm{C}\right) \rightarrow \mathrm{K}_{2} \mathrm{Mg}\left(\mathrm{CO}_{3}\right)_{2}$ $\left(1250^{\circ} \mathrm{C}\right) \rightarrow \mathrm{K}_{2} \mathrm{Ca}_{3}\left(\mathrm{CO}_{3}\right)_{4}\left(1350{ }^{\circ} \mathrm{C}\right) \rightarrow \mathrm{K}_{2} \mathrm{CO}_{3}\left(1425^{\circ} \mathrm{C}\right) \rightarrow$ dolomite $\left(1450{ }^{\circ} \mathrm{C}\right) \rightarrow \mathrm{CaCO}_{3}\left(1660{ }^{\circ} \mathrm{C}\right) \rightarrow$ magnesite $\left(1780^{\circ} \mathrm{C}\right)$. The high Ca\#t of about 40 of the $\mathrm{K}_{2}(\mathrm{Mg}, \mathrm{Ca})\left(\mathrm{CO}_{3}\right)_{2}$ compound found as inclusions in diamond suggest (1) its formation and entrapment by diamond under the $P-T$ conditions of $6 \mathrm{GPa}$ and $1100^{\circ} \mathrm{C} ;(2)$ its remelting during transport by hot kimberlite magma, and (3) repeated crystallization in inclusion that retained mantle pressure during kimberlite magma emplacement. The obtained results indicate that the $\mathrm{K}-\mathrm{Ca}-\mathrm{Mg}$ carbonate melts containing $20-40 \mathrm{~mol} \% \mathrm{~K}_{2} \mathrm{CO}_{3}$ is stable under $P-T$ conditions of $6 \mathrm{GPa}$ and $1100-1200^{\circ} \mathrm{C}$ corresponding to the base of the continental lithospheric mantle. It must be emphasized that the high alkali content in the carbonate melt is a necessary condition for its existence under geothermal conditions of the continental lithosphere, otherwise, it will simply freeze.
\end{abstract}

Keywords: double potassium carbonates; bütschliite; ultrapotassic carbonatite melt; high-pressure experiment; diamond formation; continental lithosphere

\section{Introduction}

Presence of crystalline carbonates at different mantle levels follows from the occurrence of magnesite, dolomite, calcite, and/or aragonite in spinel peridotite and eclogite xenoliths [1-3], as primary 
inclusions in Cr-pyropes derived from 100-130 km depth [4,5], and as inclusions in diamonds derived from the base of the continental lithosphere and deeper levels [6-13]. Ca-Mg carbonates also appear as rock-forming minerals and/or as inclusions in high-pressure minerals in diamondiferous ultrahigh-pressure (UHP) metamorphic rocks exhumed from 150-250 km depths [14-17].

A number of studies of 'fibrous' diamonds (diamonds with high dislocation density) from kimberlites worldwide revealed the presence of K-rich carbonatitic melt inclusions coexisting with both peridotitic and eclogitic minerals [18-25]. The inclusions retain high internal pressure suggesting the mantle origin of the entrapped melt [26]. Recently this melt was also found as micro inclusions in the central part of a gem-quality diamond crystal [27] and along the twinning plane in ancient diamonds [28]. This suggests that alkali-rich carbonate melts have been introduced into the reduced lithospheric mantle since the Archaean and that these melts could be responsible for the formation of most lithospheric diamonds [28].

It was shown experimentally that the upper mantle K-rich carbonate melts could be formed by partial melting of carbonated pelites [29-31] at pressures of 5-8 GPa. However, precise determination of the compositions of these melts and subsolidus phases controlling melting reactions in the complex natural-like systems with realistic bulk compositions involving small proportions of $\mathrm{CO}_{2}$ is problematic due to their trace amounts and the lack of stability of quenched products during polishing and electron probe microanalysis [32]. It is also difficult to determine the true position of the solidus lines in the $P-T$ space.

In contrast, the study of pure carbonate systems allows careful determination of subsolidus carbonate phases, minimum melting temperatures, and the composition of incipient melt, which facilitate the interpretation of the natural-like carbonate-bearing silicate systems.

The study of the $\mathrm{K}_{2} \mathrm{CO}_{3}-\mathrm{CaCO}_{3}-\mathrm{MgCO}_{3}$ system at 6 GPa was initiated by Shatskiy, et al. [33], who examined a binary $\mathrm{K}_{2} \mathrm{CO}_{3}-\mathrm{Ca}_{0.5} \mathrm{Mg}_{0.5}-\left(\mathrm{CO}_{3}\right)_{2}$ join. In the present work, we carried out a full study of the $\mathrm{K}_{2} \mathrm{CO}_{3}-\mathrm{CaCO}_{3}-\mathrm{MgCO}_{3}$ phase diagram involving an incomparably larger number of experimental points collected at $6 \mathrm{GPa}$ in the range of $900-1300{ }^{\circ} \mathrm{C}$ (Tables S1-S9).

\section{Materials and Methods}

Experiments were performed in a 'Discoverer-1500' DIA-type multianvil apparatus at IGM SB RAS in Novosibirsk, Russia. The inner stage of anvils consisted of eight $26 \mathrm{~mm}$ tungsten carbide cubes, "Fujilloy N-05", with $12 \mathrm{~mm}$ truncations. $\mathrm{ZrO}_{2}$ pressure media (OZ-8C, MinoYogyo Co., Ltd [34]) was shaped as a $20.5 \mathrm{~mm}$ octahedron with ground edges and corners. A multi-charge assembly allowed simultaneous loading of up to 16 samples [35]. The temperature was measured by a $W_{97} R_{3}-W_{75} R_{25}$ thermocouple and controlled automatically within $2.0^{\circ} \mathrm{C}$ of the target value. The thermocouple junction was located at the heater center in the high-temperature (HT) zone. Maximum thermal gradient across the sample charge did not exceed $5-8{ }^{\circ} \mathrm{C} / \mathrm{mm}$ at $900-1300{ }^{\circ} \mathrm{C}[35,36]$. Uncertainty in the temperature and pressure estimates are less than $20^{\circ} \mathrm{C}$ and $0.5 \mathrm{GPa}$, respectively. The cell assembly design, pressure calibration, and temperature distribution across sample charge are given in [35,36].

Since the studied system includes highly hygroscopic $\mathrm{K}_{2} \mathrm{CO}_{3}$, special care was taken to avoid the contamination of the samples by water before the experiment and to prevent damage of the post-experimental samples by atmospheric humidity during polishing. $\mathrm{K}_{2} \mathrm{CO}_{3}$-bearing samples easily absorb water from the atmospheric air. Placing the sample in a vacuum for carbon coating results in water evaporation and precipitation of needle crystals of K-phase, presumably $\mathrm{KHCO}_{3}$, on the sample surface. This prevents the chemical analysis of the obtained phases. Examples of BSE images of well-polished samples and the same samples damaged by atmospheric humidity are shown in Figure S1. The procedures of the sample preparation and polishing are described in [31,37].

Recovered samples were studied using a MIRA 3 LMU scanning electron microscope (Tescan Orsay Holding, Brno, Czech) coupled with an INCA energy-dispersive X-ray microanalysis system 450 equipped with the liquid nitrogen-free Large area EDS X-Max-80 Silicon Drift Detector (Oxford Instruments Nanoanalysis Ltd, Oxford, UK) at IGM SB RAS (see [37] for details). 


\section{Experimental Results}

The results of the experiments in the system $\mathrm{K}_{2} \mathrm{CO}_{3}-\mathrm{CaCO}_{3}-\mathrm{MgCO}_{3}$ including phase compositions of recovered samples and chemical compositions of obtained carbonate phases are summarized in Tables S1-S9. Backscattered electron (BSE) images of experimental samples are shown in Figures 1-4. The isothermal sections of the $T-X$ ternary diagram are shown in Figure 5. A list of abbreviations is given in the Nomenclature section.

Run No.; $\mathrm{K}_{2} \# / \mathrm{Ca \# ,} \mathrm{mol \% ;} \mathrm{temperature;} \mathrm{run} \mathrm{duration.}$

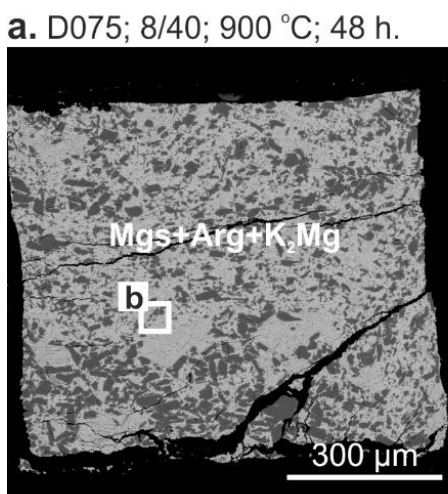

d. $\mathrm{D} 075 ; 8 / 93 ; 900^{\circ} \mathrm{C} ; 48 \mathrm{~h}$.
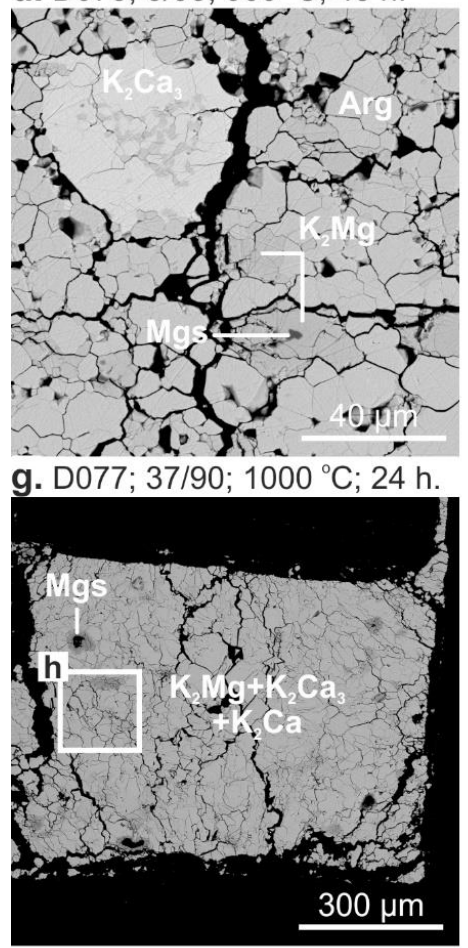
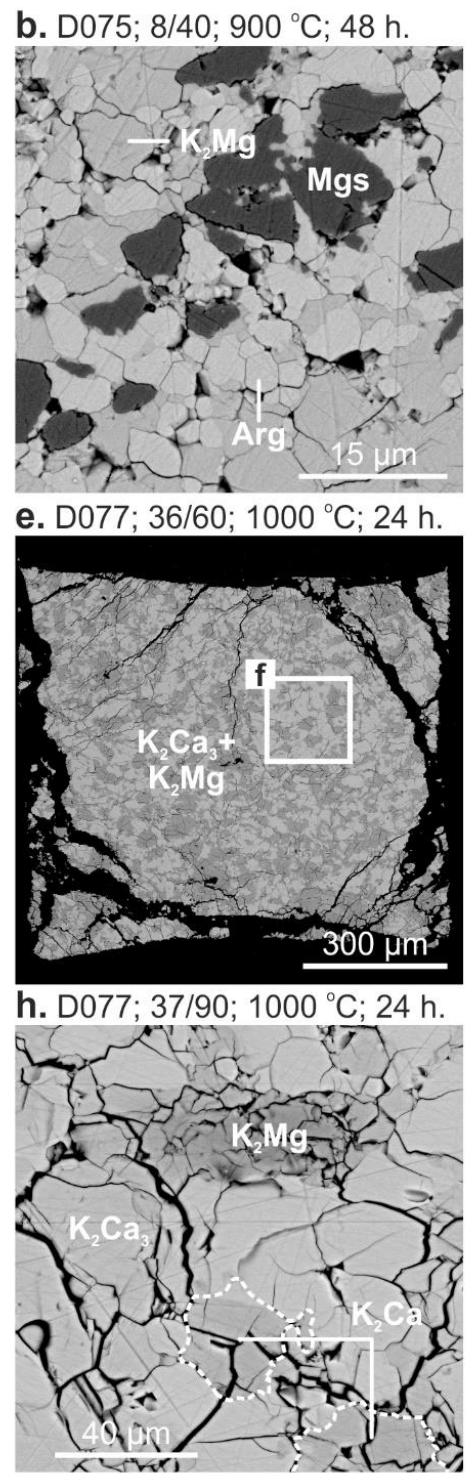

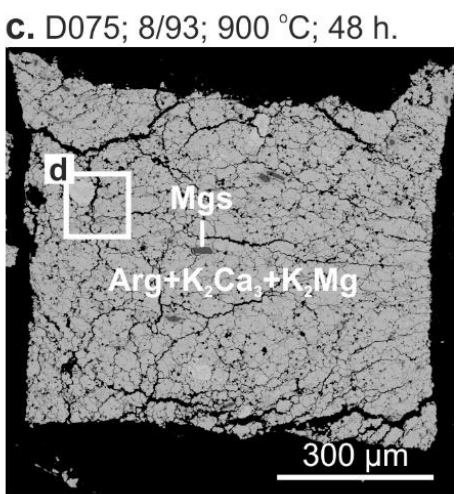

f. D077; 36/60; $1000{ }^{\circ} \mathrm{C} ; 24 \mathrm{~h}$.

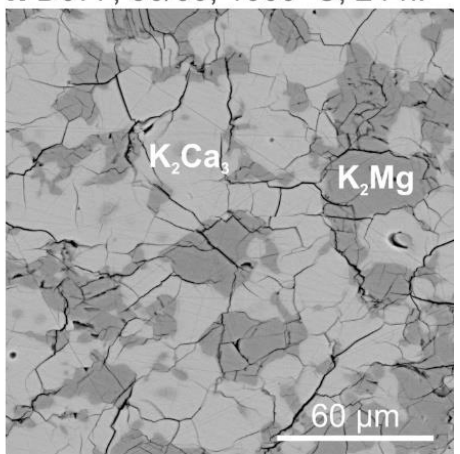

i. $\mathrm{D} 075 ; 53 / 40 ; 900^{\circ} \mathrm{C} ; 48 \mathrm{~h}$.

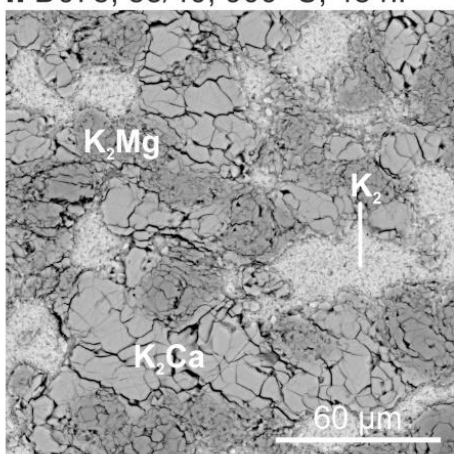

Figure 1. Backscattered electron (BSE) images of sample cross-sections illustrating subsolidus phase relationships in the system $\mathrm{K}_{2} \mathrm{CO}_{3}-\mathrm{CaCO}_{3}-\mathrm{MgCO}_{3}$ at $6 \mathrm{GPa}$. The samples represent two runs: D075 at $900{ }^{\circ} \mathrm{C}$ with a duration of $48 \mathrm{~h}(\mathrm{a}-\mathrm{d}, \mathrm{i}) ; \mathrm{D} 077$ at $1000{ }^{\circ} \mathrm{C}$ and $24 \mathrm{~h}(\mathrm{e}-\mathrm{h}) . \mathrm{K}_{2} \# / C a \#$ indicates bulk composition of the starting mixture, $\mathrm{K}_{2} \#=100 \cdot \mathrm{K}_{2} \mathrm{CO}_{3} /\left(\mathrm{K}_{2} \mathrm{CO}_{3}+\mathrm{CaCO}_{3}+\mathrm{MgCO} 3\right)$, $\mathrm{Ca} \#=100 \cdot \mathrm{CaCO}_{3} /\left(\mathrm{CaCO}_{3}+\right.$ $\mathrm{MgCO}_{3}$ ). See the Nomenclature section for abbreviations.

At $900{ }^{\circ} \mathrm{C}$ (run D075, $48 \mathrm{~h}$ ) and $1000{ }^{\circ} \mathrm{C}$ (run D077, $24 \mathrm{~h}$ ), the run products are represented by subsolidus phase assemblages (Figure $5 \mathrm{a}, \mathrm{b}$ ). Typically, the limiting reagents have been consumed completely. However, in some runs, the relicts of Mgs were observed among the run products (Figure $1 \mathrm{c}, \mathrm{d}, \mathrm{g}$ ). At these temperatures, three intermediate compounds, $\mathrm{K}_{2} \mathrm{Mg}, \mathrm{K}_{2} \mathrm{Ca}$, and $\mathrm{K}_{2} \mathrm{Ca}_{3}$, were found. Their stoichiometries resemble those in the corresponding binary systems [36,38]. The $\mathrm{K}_{2} \mathrm{Ca}_{3}$ 
and $\mathrm{K}_{2}$ Ca compounds dissolve up to 7 and 30-40 mol\% of $\mathrm{Mg}$ components, respectively, whereas $\mathrm{K}_{2} \mathrm{Mg}$ dissolves up to $17 \mathrm{~mol} \%$ of Ca component (Tables S1 and S2). The compositions of these compounds can be approximated as follows: $\mathrm{K}_{2}\left(\mathrm{Ca}_{\geq 0.93} \mathrm{Mg}_{\leq 0.07}\right)_{3}\left(\mathrm{CO}_{3}\right)_{4}, \mathrm{~K}_{2}\left(\mathrm{Ca}_{\geq 0.58} \mathrm{Mg}_{\leq 0.42}\right)\left(\mathrm{CO}_{3}\right)_{2}$, and $\mathrm{K}_{2}\left(\mathrm{Mg}_{\geq 0.83} \mathrm{Ca}_{\leq 0.17}\right)\left(\mathrm{CO}_{3}\right)_{2}$ (Tables $\mathrm{S} 1$ and S2). Although a mutual solubility of $\mathrm{K}_{2} \mathrm{Mg}$ and $\mathrm{K}_{2} \mathrm{Ca}$ compounds is noticeable, a miscibility gap between these phases was observed (Figures $1 \mathrm{i}$ and $5 \mathrm{a}, \mathrm{b}$, and Tables S1 and S2). It was previously shown that at $6 \mathrm{GPa}, \mathrm{K}_{2} \mathrm{Ca}\left(\mathrm{CO}_{3}\right)_{2}$ bütschliite decomposes between 950 and $1000{ }^{\circ} \mathrm{C}$ according to the reaction [38,39]:

$$
9 \mathrm{~K}_{2} \mathrm{Ca}\left(\mathrm{CO}_{3}\right)_{2} \text { (bütschliite) } \rightarrow 2 \mathrm{~K}_{8} \mathrm{Ca}_{3}\left(\mathrm{CO}_{3}\right)_{7}+\mathrm{K}_{2} \mathrm{Ca}_{3}\left(\mathrm{CO}_{3}\right)_{4} \text {. }
$$

Our results suggest that the partial substitution of Ca with $\mathrm{Mg}$ extends its stability to $1000{ }^{\circ} \mathrm{C}$ (Figure $5 b$ ). $\mathrm{K}_{2} \mathrm{CO}_{3}$ dissolves up to $2 \mathrm{~mol} \% \mathrm{CaCO}_{3}$ and minor amounts of $\mathrm{MgCO}_{3}$ (Figure $5 \mathrm{a}$,b, Tables S1 and S2).

The following three-phase regions were established at 900 and $1000{ }^{\circ} \mathrm{C}$ (Figure 5a,b): $\mathrm{Mgs}+\mathrm{Arg}+$ $\mathrm{K}_{2} \mathrm{Mg}$ (Figure 1a,b), Arg $+\mathrm{K}_{2} \mathrm{Ca}_{3}+\mathrm{K}_{2} \mathrm{Mg}$ (Figure 1c,d), $\mathrm{K}_{2} \mathrm{Mg}+\mathrm{K}_{2} \mathrm{Ca}_{3}+\mathrm{K}_{2} \mathrm{Ca}$ (Figure 1g,h), and $\mathrm{K}_{2}+$ $\mathrm{K}_{2} \mathrm{Mg}+\mathrm{K}_{2} \mathrm{Ca}$ (Figure 1i), while the two-phase fields include $\mathrm{Arg}+\mathrm{K}_{2} \mathrm{Ca}_{3}, \mathrm{Arg}+\mathrm{K}_{2} \mathrm{Mg}, \mathrm{K}_{2} \mathrm{Ca}_{3}+\mathrm{K}_{2} \mathrm{Ca}$, $\mathrm{K}_{2} \mathrm{Ca}_{3}+\mathrm{K}_{2} \mathrm{Mg}$ (Figure 1e,f), $\mathrm{K}_{2} \mathrm{Ca}+\mathrm{K}_{2}, \mathrm{~K}_{2} \mathrm{Ca}+\mathrm{K}_{2} \mathrm{Mg}, \mathrm{Mgs}+\mathrm{K}_{2} \mathrm{Mg}$, and $\mathrm{K}_{2} \mathrm{Mg}+\mathrm{K}_{2}$. According to the phase relations established in the binary $\mathrm{K}_{2} \mathrm{CO}_{3}-\mathrm{CaCO}_{3}$ system, $\mathrm{K}_{8} \mathrm{Ca}_{3}$ compound is stable at $900{ }^{\circ} \mathrm{C}$ and disappears via congruent melting above $1200{ }^{\circ} \mathrm{C}$ [38]. This suggests the existence of narrow three- and two-phase fields containing $\mathrm{K}_{8} \mathrm{Ca}_{3}$ (Figure $5 \mathrm{a}, \mathrm{b}$ ).

As temperature increases to $1100{ }^{\circ} \mathrm{C}$ (runs D078, $47 \mathrm{~h}$ and D158, $6 \mathrm{~h}$ ), the diagram undergoes significant changes including an appearance of two liquid fields, $\mathrm{K}_{8}\left(\mathrm{Ca}_{\geq 0.97} \mathrm{Mg}_{\leq 0.03}\right)_{3}\left(\mathrm{CO}_{3}\right)_{7}$, and Ca-Dol (Ca\# 5-7) and disappearance of Mg-bearing $\mathrm{K}_{2} \mathrm{Ca}$ (Figure 5e, Tables S3 and S4). The appearance of $\mathrm{Ca}-\mathrm{Dol}$ is consistent with the phase relations established in the $\mathrm{CaCO}_{3}-\mathrm{MgCO}_{3}$ system [35]. The isothermal section contains two subsolidus three-phase fields: $\mathrm{Mgs}+\mathrm{K}_{2} \mathrm{Ca}_{3}+\mathrm{Dol}$ (Figure 2a), Arg $+\mathrm{K}_{2} \mathrm{Ca}_{3}+\mathrm{Ca}-\mathrm{Dol}$ (Figure $2 \mathrm{~b}$ ) and five subsolidus two-phase fields: Arg $+\mathrm{K}_{2} \mathrm{Ca}_{3}, \mathrm{~K}_{2} \mathrm{Ca}_{3}+\mathrm{K}_{8} \mathrm{Ca}_{3}$, $\mathrm{K}_{8} \mathrm{Ca}_{3}+\mathrm{K}_{2}, \mathrm{Dol}+\mathrm{K}_{2} \mathrm{Ca}_{3}, \mathrm{Mgs}+\mathrm{K}_{2} \mathrm{Mg}$, and $\mathrm{K}_{2} \mathrm{Mg}+\mathrm{K}_{2}$ (Figure 5e). One liquid field is surrounded by four two-phase fields: $\mathrm{K}_{2} \mathrm{Ca}_{3}+\mathrm{L}_{\mathrm{E} 1}, \mathrm{~K}_{8} \mathrm{Ca}_{3}+\mathrm{L}_{\mathrm{E} 1}, \mathrm{~K}_{2} \mathrm{Mg}+\mathrm{L}_{\mathrm{E} 1}$, (Figure 2f,i), and Mgs $+\mathrm{L}_{\mathrm{E} 1}$ and four three-phase fields: $\mathrm{K}_{2} \mathrm{Ca}_{3}+\mathrm{K}_{8} \mathrm{Ca}_{3}+\mathrm{L}_{\mathrm{E} 1}$ (Figure $2 \mathrm{~h}$ ), $\mathrm{K}_{8} \mathrm{Ca}_{3}+\mathrm{K}_{2} \mathrm{Ca}+\mathrm{L}_{\mathrm{E} 1}, \mathrm{~K}_{2} \mathrm{Mg}+\mathrm{Mgs}+\mathrm{L}_{\mathrm{E} 1}$ (Figure 2c,e), and $\mathrm{Mgs}+\mathrm{Dol}+\mathrm{L}_{\mathrm{E} 1}$ (Figure 5e). At $1100{ }^{\circ} \mathrm{C}$, the $\mathrm{L}_{\mathrm{E} 1}$ composition varies in the range of $32-54 \mathrm{~mol} \% \mathrm{~K}_{2} \mathrm{CO}_{3}$ and $\mathrm{Ca \#}=56-84 \mathrm{~mol} \%$ (Figure $5 \mathrm{e}$ and Tables S3 and S4). Another liquid field is surrounded by three two-phase fields including $\mathrm{K}_{8} \mathrm{Ca}_{3}+\mathrm{L}_{\mathrm{E} 2}$ (Figure 2j), $\mathrm{K}_{2}+\mathrm{L}$ (Figure 21), and $\mathrm{K}_{2} \mathrm{Mg}$ $+\mathrm{L}$ and three three-phase fields: $\mathrm{K}_{8} \mathrm{Ca}_{3}+\mathrm{K}_{2}+\mathrm{L}_{\mathrm{E} 2}$ (Figure $2 \mathrm{k}$ ), $\mathrm{K}_{2}+\mathrm{K}_{2} \mathrm{Mg}+\mathrm{L}_{\mathrm{E} 2}$, and $\mathrm{K}_{2} \mathrm{Mg}+\mathrm{K}_{8} \mathrm{Ca}_{3}+$ $\mathrm{L}_{\mathrm{E} 2}$ (Figure 5e). In this field, the melt composition $\mathrm{L}_{\mathrm{E} 2}$ varies in the range of $57-66 \mathrm{~mol} \% \mathrm{~K}_{2} \mathrm{CO}_{3}$ and Ca\# = 45-84 mol\%.

Some samples recovered from the $1100{ }^{\circ} \mathrm{C}$ experiments contain subsolidus assemblages at their low-temperature (LT) side. Given the thermal gradient across the sample charge, $6-7^{\circ} \mathrm{C} / \mathrm{mm}$ at $1100{ }^{\circ} \mathrm{C}$, and the longest distance from the thermocouple junction to the sample end, $2.5-3.0 \mathrm{~mm}$, the temperature at the LT side was about $1080^{\circ} \mathrm{C}$ in the runs at $1100{ }^{\circ} \mathrm{C}$. Phase relations inferred from the LT samples sides are shown in Figure 5c. The results suggest that temperature increase from 1000 to $1080{ }^{\circ} \mathrm{C}$, the $\mathrm{Arg}+\mathrm{K}_{2} \mathrm{Mg}$ assemblage becomes prohibited owing to the following subsolidus reaction:

$$
\mathrm{CaCO}_{3}(\mathrm{Arg})+\mathrm{K}_{2} \mathrm{Mg}\left(\mathrm{CO}_{3}\right)_{2} \rightarrow \mathrm{CaMg}\left(\mathrm{CO}_{3}\right)_{2}(\mathrm{Dol})+\mathrm{K}_{2} \mathrm{Ca}_{3}\left(\mathrm{CO}_{3}\right)_{4} \text {. }
$$

Reaction (2) changes subsolidus assemblages in the join $\mathrm{Mgs}-\mathrm{Arg}-\mathrm{K}_{2} \mathrm{Ca}_{3}-\mathrm{K}_{2} \mathrm{Mg}$ and yields an appearance of the following three-phase fields: $\mathrm{K}_{2} \mathrm{Mg}+\mathrm{Mgs}+\mathrm{K}_{2} \mathrm{Ca}_{3}$ (Figure 2c,d), $\mathrm{Mgs}+\mathrm{Dol}+$ $\mathrm{K}_{2} \mathrm{Ca}_{3}$ (Figure 2a), and $\mathrm{Ca}-\mathrm{Dol}+\mathrm{Arg}+\mathrm{K}_{2} \mathrm{Ca}_{3}$ (Figures $2 \mathrm{~b}$ and $5 \mathrm{c}$ ). Considering subsolidus phase relations at $\sim 1080{ }^{\circ} \mathrm{C}$ (Figure $5 \mathrm{c}$ ) and melting phase relations at $1100{ }^{\circ} \mathrm{C}$ (Figure 5e), the system has two eutectics controlled by the following four-phase reactions (Figure $5 \mathrm{~d}$ and Table S10). 
Eutectic $\mathrm{E}^{1}: 10.59 \mathrm{~K}_{2}\left(\mathrm{Ca}_{0.9} \mathrm{Mg}_{0.1}\right)_{3}\left(\mathrm{CO}_{3}\right)_{4}\left(\mathrm{~K}_{2} \mathrm{Ca}_{3}\right)+1.18 \mathrm{~K}_{8} \mathrm{Ca}_{3}\left(\mathrm{CO}_{3}\right)_{7}\left(\mathrm{~K}_{8} \mathrm{Ca}_{3}\right)+$ $24.71 \mathrm{~K}_{2}\left(\mathrm{Mg}_{0.6} \mathrm{Ca}_{0.4}\right)\left(\mathrm{CO}_{3}\right)_{2}\left(\mathrm{~K}_{2} \mathrm{Mg}\right)=\left[40 \mathrm{~K}_{2} \mathrm{CO}_{3} \cdot 60\left(\mathrm{Ca}_{0.70} \mathrm{Mg}_{0.30}\right) \mathrm{CO}_{3}\right]\left(\mathrm{L}_{\mathrm{E} 1}\right)$

Eutectic $\mathrm{E}^{2}: 17.03 \mathrm{~K}_{2} \mathrm{CO}_{3}\left(\mathrm{~K}_{2}\right)+6.97 \mathrm{~K}_{8} \mathrm{Ca}_{3}\left(\mathrm{CO}_{3}\right)_{7}\left(\mathrm{~K}_{8} \mathrm{Ca}_{3}\right)+17.10 \mathrm{~K}_{2}\left(\mathrm{Mg}_{0.6} \mathrm{Ca}_{0.4}\right)\left(\mathrm{CO}_{3}\right)_{2}$

$\left(\mathrm{K}_{2} \mathrm{Mg}\right)=\left[62 \mathrm{~K}_{2} \mathrm{CO}_{3} \cdot 38\left(\mathrm{Ca}_{0.73} \mathrm{Mg}_{0.27}\right) \mathrm{CO}_{3}\right]\left(\mathrm{L}_{\mathrm{E} 2}\right)$

Run No.; $\mathrm{K}_{2} \# / \mathrm{Ca \# ,} \mathrm{mol \% ;} \mathrm{temperature;} \mathrm{run} \mathrm{duration.}$

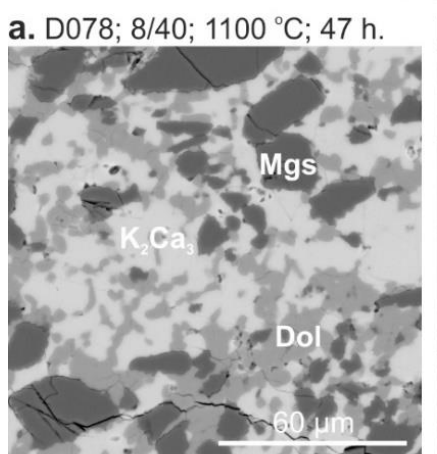

d. $\mathrm{D} 078 ; 25 / 25 ; 1100{ }^{\circ} \mathrm{C} ; 47 \mathrm{~h}$.

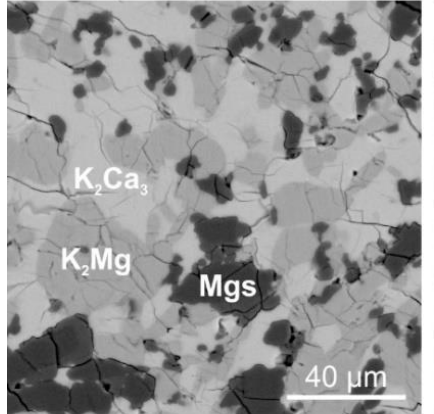

g. D078; $45 / 35 ; 1100{ }^{\circ} \mathrm{C} ; 47 \mathrm{~h}$.
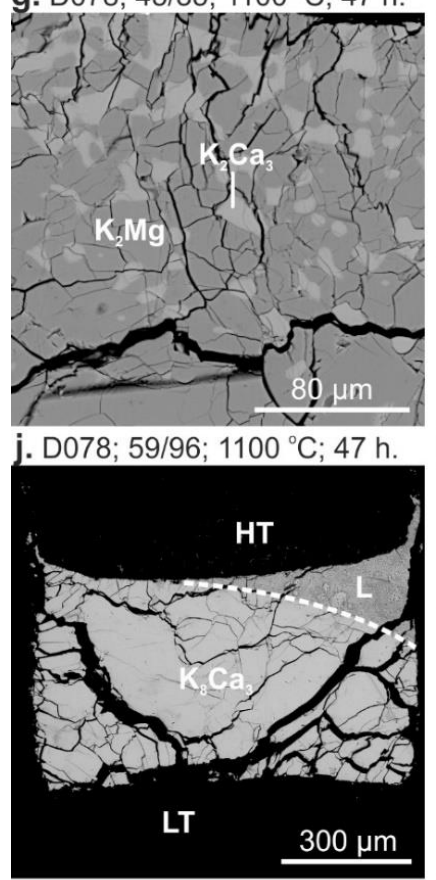

b. $\mathrm{D} 078 ; 8 / 75 ; 1100{ }^{\circ} \mathrm{C} ; 47 \mathrm{~h}$.
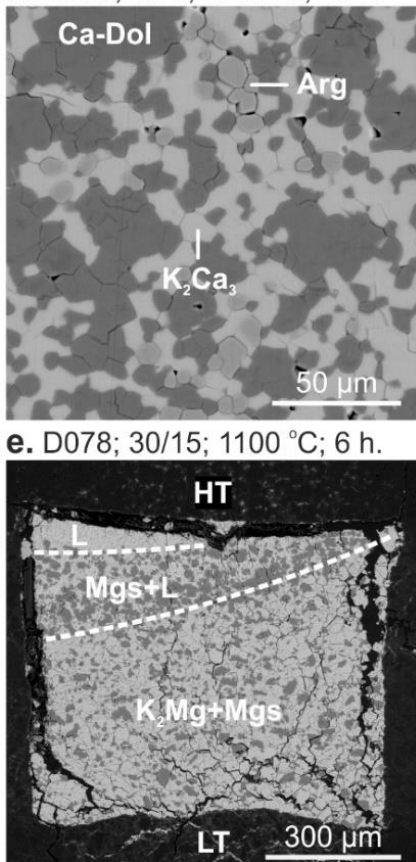

h. D078, 49/90, $1100^{\circ} \mathrm{C}, 47 \mathrm{~h}$.

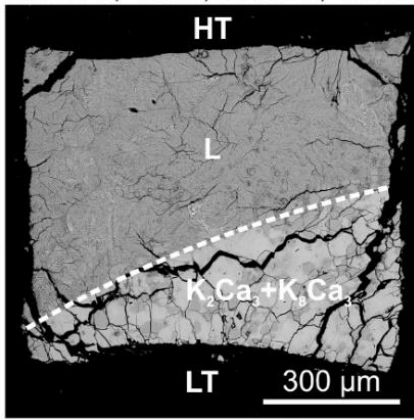

k. D158; 64/92; $1100{ }^{\circ} \mathrm{C} ; 6 \mathrm{~h}$.

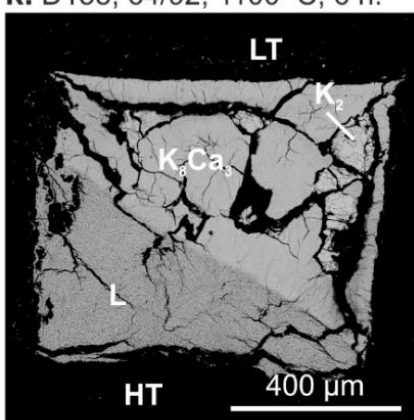

C. $\mathrm{D} 078 ; 25 / 25 ; 1100^{\circ} \mathrm{C} ; 47 \mathrm{~h}$

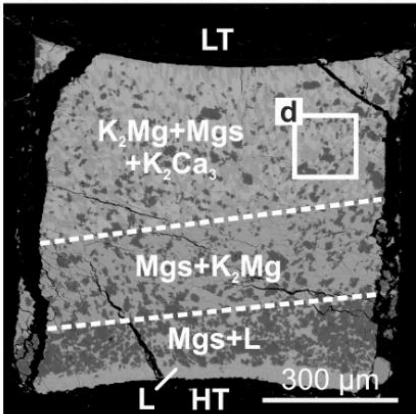

f. $D 078 ; 45 / 35 ; 1100{ }^{\circ} \mathrm{C} ; 47 \mathrm{~h}$.

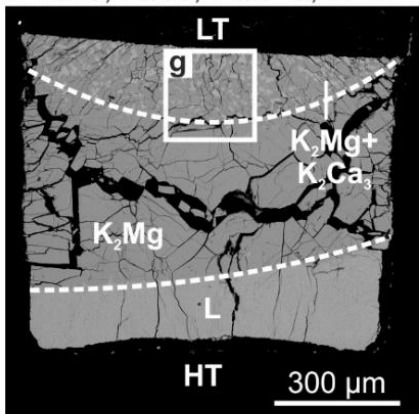

i. D158; 50/25; $1100^{\circ} \mathrm{C} ; 6 \mathrm{~h}$.

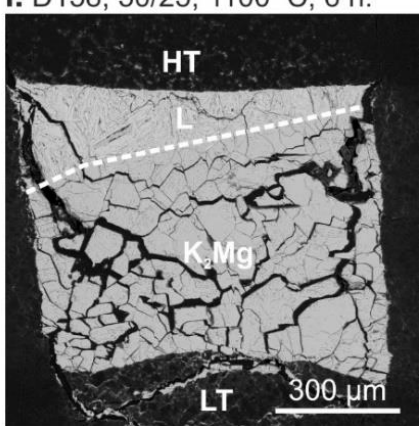

I. D158; 80/50; $1100{ }^{\circ} \mathrm{C} ; 6$ h.

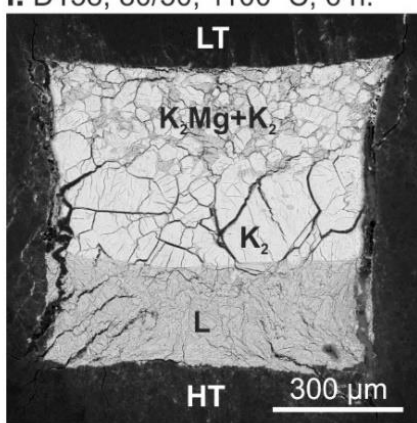

Figure 2. BSE images of sample cross-sections illustrating phase relationships in the system $\mathrm{K}_{2} \mathrm{CO}_{3}-\mathrm{CaCO}_{3}-\mathrm{MgCO}_{3}$ at $6 \mathrm{GPa}$ and $1100{ }^{\circ} \mathrm{C}$. $\mathrm{K}_{2} \# / \mathrm{Ca} \#$ indicates bulk composition of the starting mixture, $\mathrm{K}_{2} \#=100 \cdot \mathrm{K}_{2} \mathrm{CO}_{3} /\left(\mathrm{K}_{2} \mathrm{CO}_{3}+\mathrm{CaCO}_{3}+\mathrm{MgCO}\right), \mathrm{Ca} \#=100 \cdot \mathrm{CaCO}_{3} /\left(\mathrm{CaCO}_{3}+\mathrm{MgCO}_{3}\right)$. LT-low-temperature side. HT-high-temperature side. See the Nomenclature section for abbreviations. 
Run No.; $\mathrm{K}_{2} \# / \mathrm{Ca \# ,} \mathrm{mol \% ;} \mathrm{temperature;} \mathrm{run} \mathrm{duration.}$

a. D079; 8/40; $1200^{\circ} \mathrm{C} ; 25 \mathrm{~h}$.

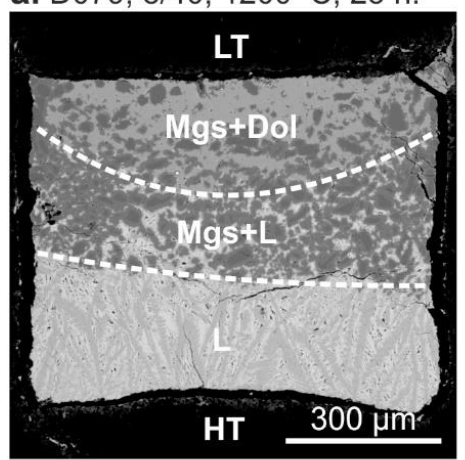

d. D079; 14/92; $1200^{\circ} \mathrm{C} ; 25 \mathrm{~h}$.

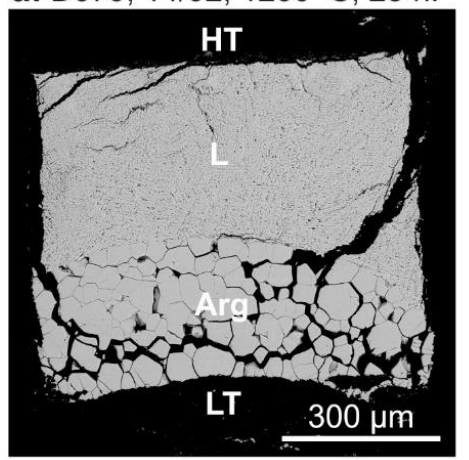

g. D162; 16/70; $1200^{\circ} \mathrm{C} ; 4$ h.

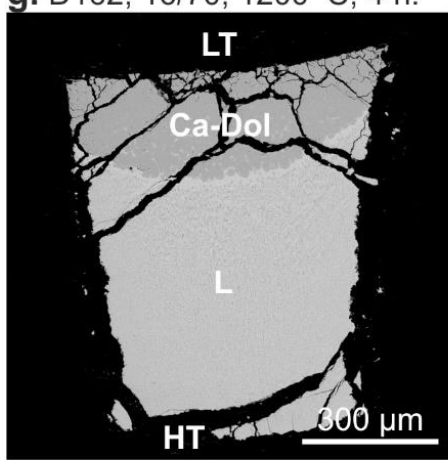

j. D079; 27/90; $1200{ }^{\circ} \mathrm{C} ; 25$ h.

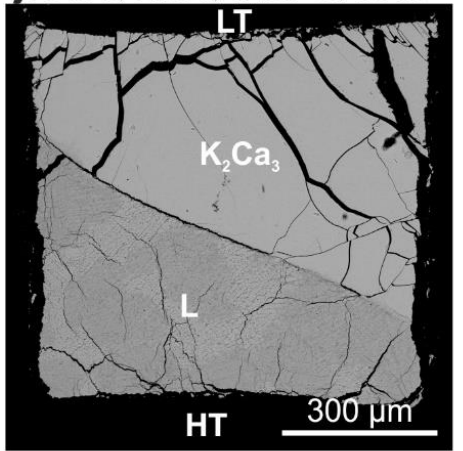

b. $\mathrm{D} 162 ; 8 / 93 ; 1200^{\circ} \mathrm{C} ; 4 \mathrm{~h}$.

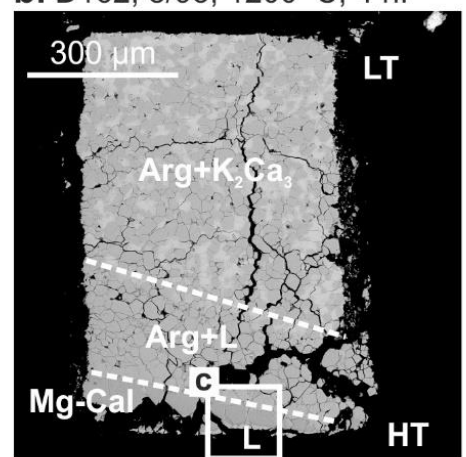

e. $\mathrm{D} 162 ; 18 / 93 ; 1200^{\circ} \mathrm{C} ; 4 \mathrm{~h}$.

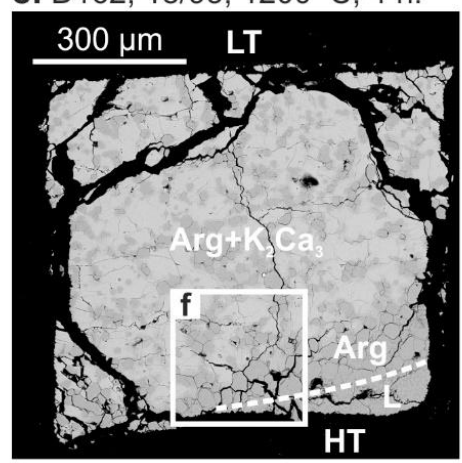

h. $\mathrm{D} 162 ; 30 / 15 ; 1200^{\circ} \mathrm{C} ; 4$ h.

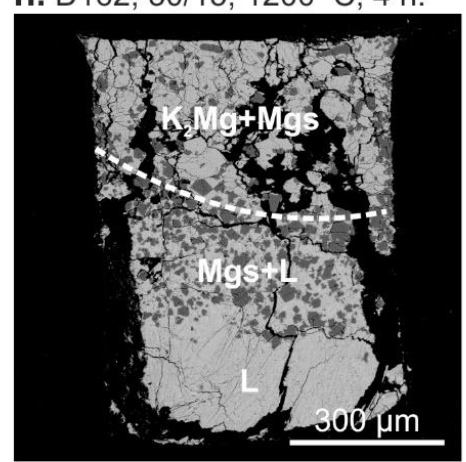

k. D172; 50/25; $1200^{\circ} \mathrm{C} ; 10 \mathrm{~h}$

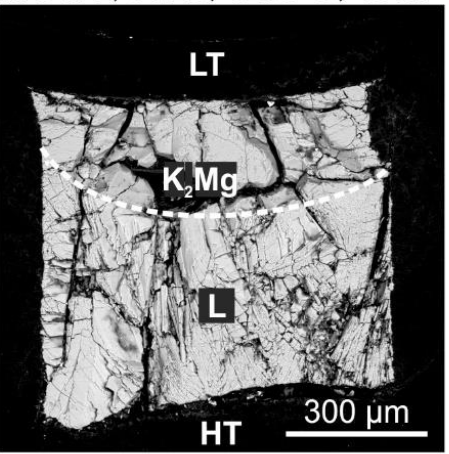

c. $\mathrm{D} 162 ; 8 / 93 ; 1200^{\circ} \mathrm{C} ; 4 \mathrm{~h}$.

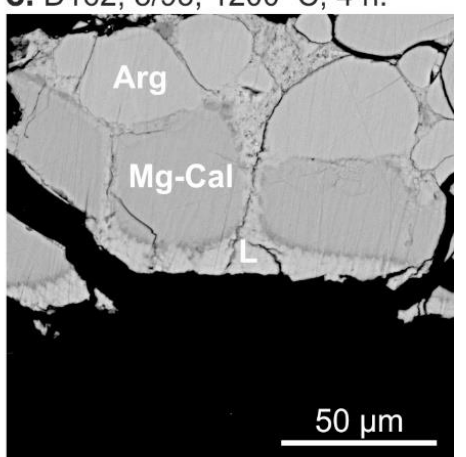

f. $\mathrm{D} 162 ; 18 / 93 ; 1200{ }^{\circ} \mathrm{C} ; 4 \mathrm{~h}$.

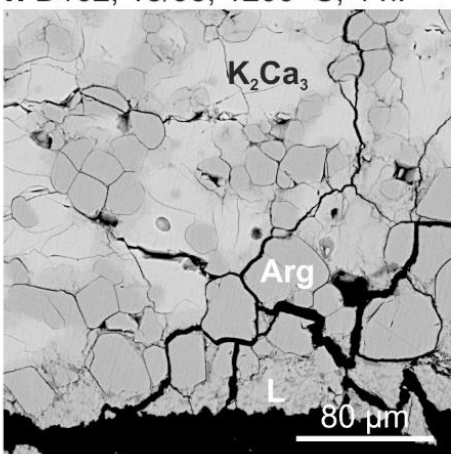

i. D079; $25 / 25 ; 1200{ }^{\circ} \mathrm{C} ; 25 \mathrm{~h}$.

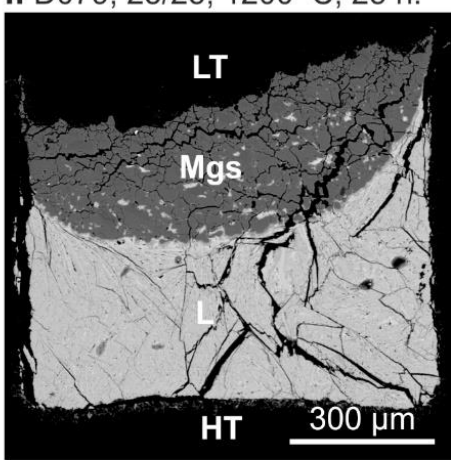

I. D162; 90/55; $1200{ }^{\circ} \mathrm{C} ; 4$ h.

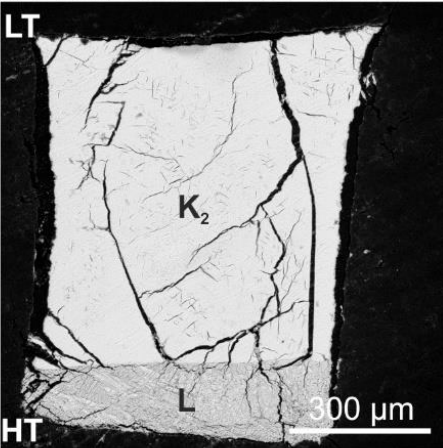

Figure 3. BSE images of sample cross-sections illustrating phase relationships in the system $\mathrm{K}_{2} \mathrm{CO}_{3}-\mathrm{CaCO}_{3}-\mathrm{MgCO}_{3}$ at $6 \mathrm{GPa}$ and $1200{ }^{\circ} \mathrm{C}$. $\mathrm{K}_{2} \# / \mathrm{Ca \#}$ indicates bulk compositions of the starting mixtures, $\mathrm{K}_{2} \#=100 \cdot \mathrm{K}_{2} \mathrm{CO}_{3} /\left(\mathrm{K}_{2} \mathrm{CO}_{3}+\mathrm{CaCO}_{3}+\mathrm{MgCO}\right)$, $\mathrm{Ca} \#=100 \cdot \mathrm{CaCO}_{3} /\left(\mathrm{CaCO}_{3}+\mathrm{MgCO} 3\right)$. LT-low-temperature side. HT-high-temperature side. See the Nomenclature section for abbreviations. 
Run No.; $\mathrm{K}_{2} \# / \mathrm{Ca \# ,} \mathrm{mol \% ;} \mathrm{temperature;} \mathrm{run} \mathrm{duration.}$
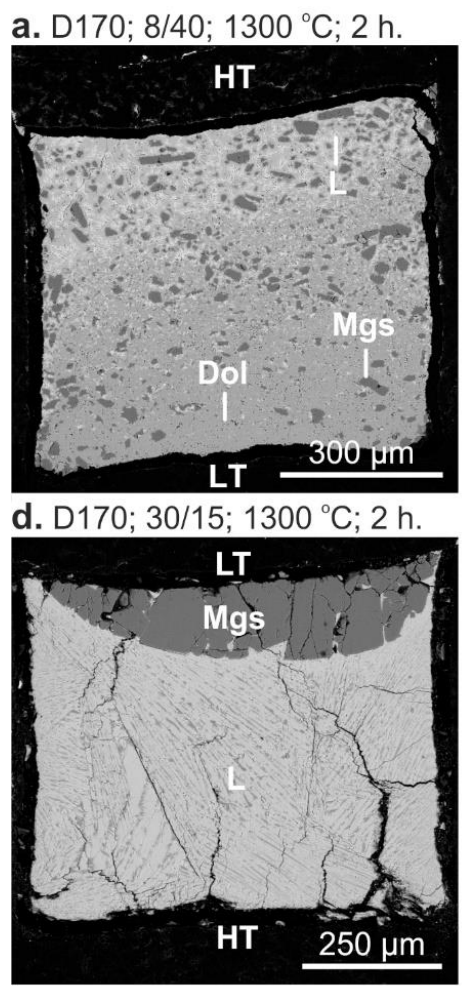

b. D170; 8/75; $1300^{\circ} \mathrm{C} ; 2 \mathrm{~h}$.

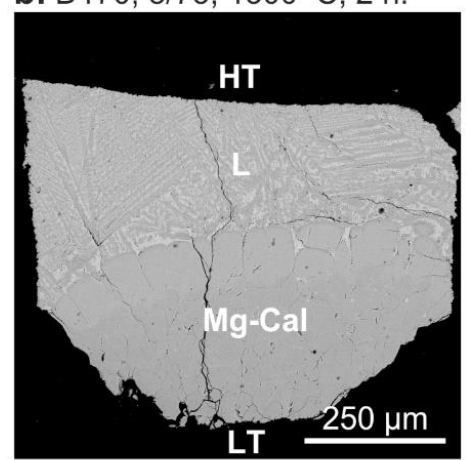

e. $\mathrm{D} 169 ; 40 / 5 ; 1250{ }^{\circ} \mathrm{C} ; 4 \mathrm{~h}$.

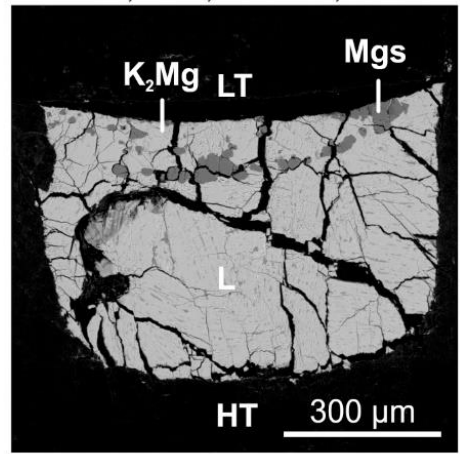

c. D169; $18 / 92 ; 1250^{\circ} \mathrm{C} ; 4 \mathrm{~h}$.

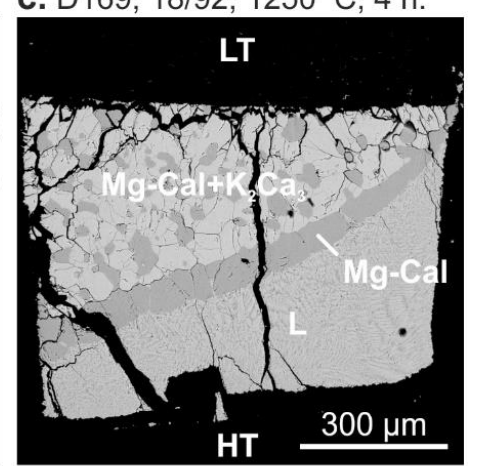

f. D170; 90/55; $1300{ }^{\circ} \mathrm{C} ; 2$ h.

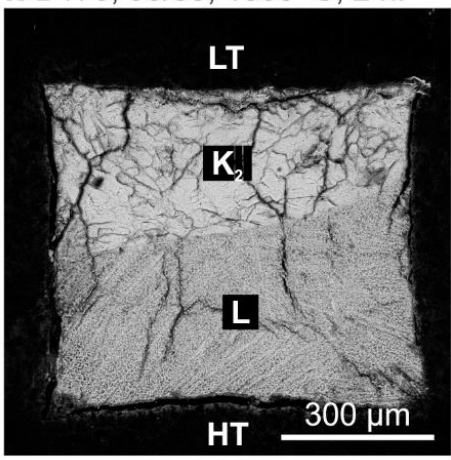

Figure 4. BSE images of sample cross-sections illustrating phase relationships in the system $\mathrm{K}_{2} \mathrm{CO}_{3}-\mathrm{CaCO}_{3}-\mathrm{MgCO}_{3}$ at $6 \mathrm{GPa}$ and $1250-1300{ }^{\circ} \mathrm{C}$. $\mathrm{K}_{2} \# / \mathrm{Ca} \#$ indicates bulk composition of the starting mixture, $\mathrm{K}_{2} \#=100 \cdot \mathrm{K}_{2} \mathrm{CO}_{3} /\left(\mathrm{K}_{2} \mathrm{CO}_{3}+\mathrm{CaCO}_{3}+\mathrm{MgCO} 3\right), \mathrm{Ca} \#=100 \cdot \mathrm{CaCO}_{3} /\left(\mathrm{CaCO}_{3}+\mathrm{MgCO}_{3}\right)$. LT-low-temperature side. HT-high-temperature side. See the Nomenclature section for abbreviations.

As temperature increases to $1200{ }^{\circ} \mathrm{C}$ (runs D079, $25 \mathrm{~h}$; D162, $4 \mathrm{~h}$; D162, $10 \mathrm{~h}$ ), the liquid fields remarkably expand and combine into a single one (Figure $5 \mathrm{f}$ ). This field is surrounded by seven two-phase fields: Mgs + L (Figure 3i), Dol + L (Figure 3g), Arg + L (Figure 3d), $\mathrm{K}_{2} \mathrm{Ca}_{3}+\mathrm{L}$ (Figure 3j), $\mathrm{K}_{8} \mathrm{Ca}_{3}+\mathrm{L}, \mathrm{K}_{2}+\mathrm{L}$ (Figure 31), $\mathrm{K}_{2} \mathrm{Mg}+\mathrm{L}$ (Figure 3k) and four three-phase fields: $\mathrm{K}_{2} \mathrm{Mg}+\mathrm{Mgs}+\mathrm{L}$ (Figure 3h), Mgs + Dol + L (Figure 3a), Mg-Cal + Arg + L (Figure 3b,c), Arg + $\mathrm{K}_{2} \mathrm{Ca}_{3}+\mathrm{L}$ (Figure 3e,f)

With a further increase in temperature, the melt region continues to expand, while the number of two-phase and three-phase fields decreases (Figure 5g,h). At $1250{ }^{\circ} \mathrm{C}$ (run D169, 4h), the $\mathrm{K}_{8} \mathrm{Ca}_{3}+\mathrm{L}$ and $\mathrm{Mgs}+\mathrm{K}_{2} \mathrm{Mg}$ fields disappear. The isothermal section includes seven two-phase fields: $\mathrm{Mgs}+\mathrm{L}$, $\mathrm{Dol}+\mathrm{L}, \mathrm{Arg}+\mathrm{L}, \mathrm{Arg}+\mathrm{K}_{2} \mathrm{Ca}_{3}, \mathrm{~K}_{2} \mathrm{Ca}_{3}+\mathrm{L}, \mathrm{K}_{2}+\mathrm{L}, \mathrm{K}_{2} \mathrm{Mg}+\mathrm{L}$ and four three-phase fields: $\mathrm{K}_{2} \mathrm{Mg}+\mathrm{Mgs}$ $+\mathrm{L}$ (Figure 4e), Mgs + Dol + L, Mg-Cal + Arg + L, Arg + $\mathrm{K}_{2} \mathrm{Ca}_{3}+\mathrm{L}$ (Figure 4c). Most of these fields remain at $1300{ }^{\circ} \mathrm{C}$ (run D170, $2 \mathrm{~h}$ ), such as Mgs $+\mathrm{L}$ (Figure 3d), Dol + L (Figure 3b), $\mathrm{K}_{2}+\mathrm{L}$ (Figure 3f), $\mathrm{Mgs}+\mathrm{Dol}+\mathrm{L}$ (Figure 4a), while the Arg $+\mathrm{K}_{2} \mathrm{Ca}_{3}, \mathrm{Arg}+\mathrm{K}_{2} \mathrm{Ca}_{3}+\mathrm{L}, \mathrm{K}_{2} \mathrm{Mg}+\mathrm{L}$, and $\mathrm{K}_{2} \mathrm{Mg}+\mathrm{Mgs}+\mathrm{L}$ disappear (Figure 5h).

Regardless of the temperature and the composition of the starting mixture, the maximum $\mathrm{CaCO}_{3}$ and $\mathrm{MgCO}_{3}$ contents established in potassium carbonate are less than 3 and $1 \mathrm{~mol} \%$, respectively (Figure 5 and Tables S1-S9). The $\mathrm{K}_{2} \mathrm{CO}_{3}$ content in alkaline earth carbonates (aragonite, calcite, calcite-dolomite solid solutions, and magnesite) varies within the uncertainty of our EDS measurements (i.e., $<0.5 \mathrm{~mol} \%$ ) (Tables S1-S9).

Liquidus phase relations in the $\mathrm{K}_{2} \mathrm{CO}_{3}-\mathrm{CaCO}_{3}-\mathrm{MgCO}_{3}$ system are illustrated in Figure 6. There are eight primary solidification phase fields characterized by the initial crystallization of Mgs (Figures $3 \mathrm{i}$ and $4 \mathrm{~d}$ ), Arg (Figure 3d), Dol, Ca-Dol (Figures $3 \mathrm{~g}$ and $4 \mathrm{~b}$ ), $\mathrm{K}_{2} \mathrm{Ca}_{3}$ (Figure 3j), $\mathrm{K}_{8} \mathrm{Ca}_{3}$ (Figure 2j), 
$\mathrm{K}_{2} \mathrm{Mg}$ (Figures $2 \mathrm{i}$ and $3 \mathrm{k}$ ), and $\mathrm{K}_{2}$ (Figures $2 \mathrm{l}, 3 \mathrm{l}$ and $4 \mathrm{f}$ ). The system has four ternary peritectic points, controlled by the following reactions:

$$
\begin{aligned}
& \text { Peritectic } \mathrm{P}^{1}: \mathrm{K}_{2} \mathrm{Ca}_{3}+\mathrm{K}_{2} \mathrm{Mg} \rightarrow \mathrm{Mgs}+\mathrm{L} \text {, between } 1050 \text { and } 1100{ }^{\circ} \mathrm{C} \\
& \text { Peritectic } \mathrm{P}^{2}: \mathrm{K}_{2} \mathrm{Ca}_{3}+\mathrm{Mgs} \rightarrow \mathrm{Ca}-\mathrm{Dol}+\mathrm{L} \text {, between } 1100 \text { and } 1200{ }^{\circ} \mathrm{C} \\
& \text { Peritectic } \mathrm{P}^{3}: \mathrm{K}_{2} \mathrm{Ca}_{3}+\mathrm{Ca}-\mathrm{Dol} \rightarrow \mathrm{Arg}+\mathrm{L} \text {, between } 1100 \text { and } 1200{ }^{\circ} \mathrm{C} \\
& \text { Peritectic } \mathrm{P}^{4}: \mathrm{Ca}-\mathrm{Dol}+\mathrm{Mgs} \rightarrow \mathrm{Dol}+\mathrm{L} \text {, between } 1300 \text { and } 1400{ }^{\circ} \mathrm{C}
\end{aligned}
$$

and two eutectic points $\left(\mathrm{E}^{1}\right.$ and $\left.\mathrm{E}^{2}\right)$ located just below $1100{ }^{\circ} \mathrm{C}$ and controlled by Reactions (3) and (4), respectively (Figure 6).

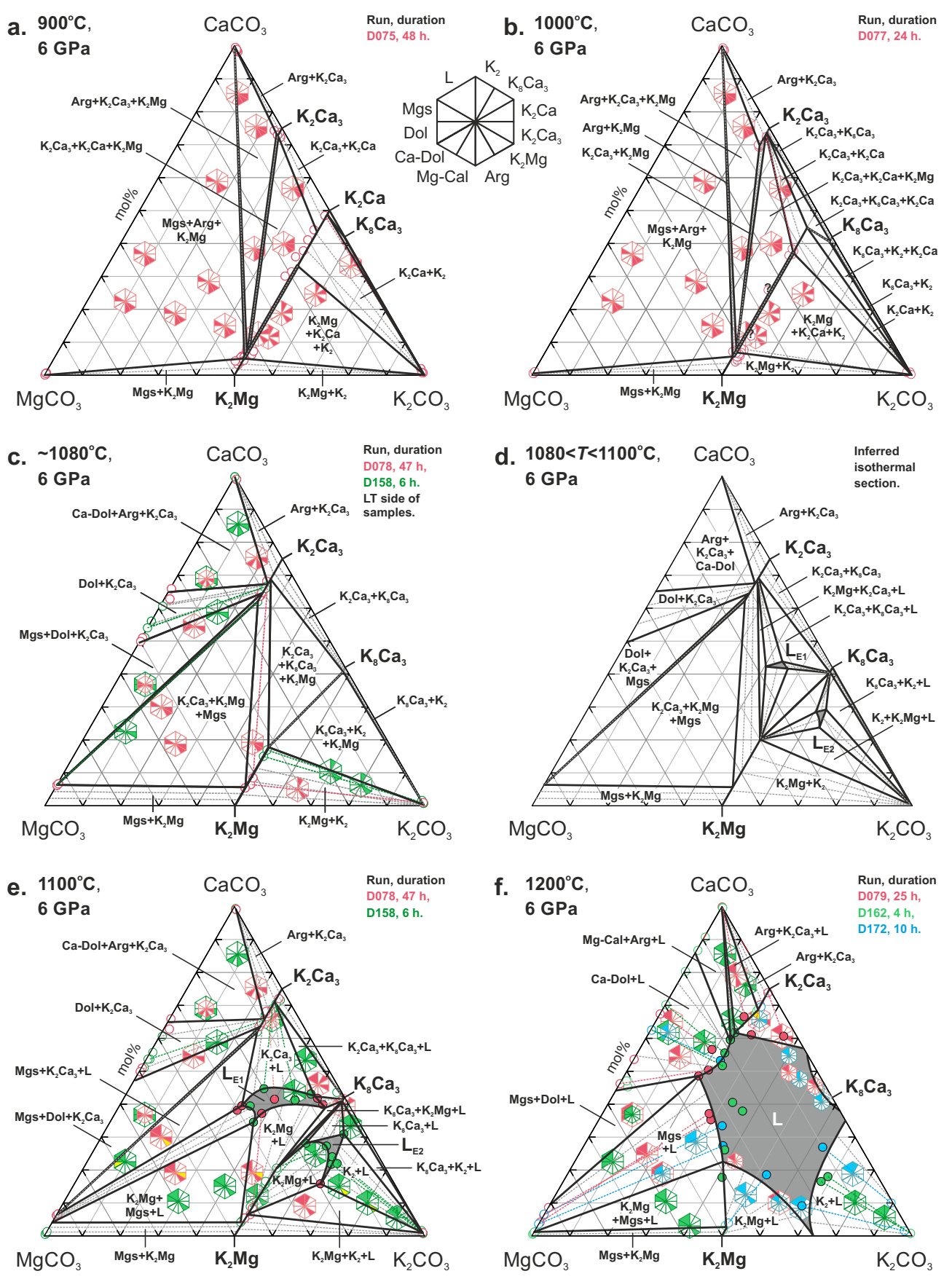

Figure 5. Cont. 

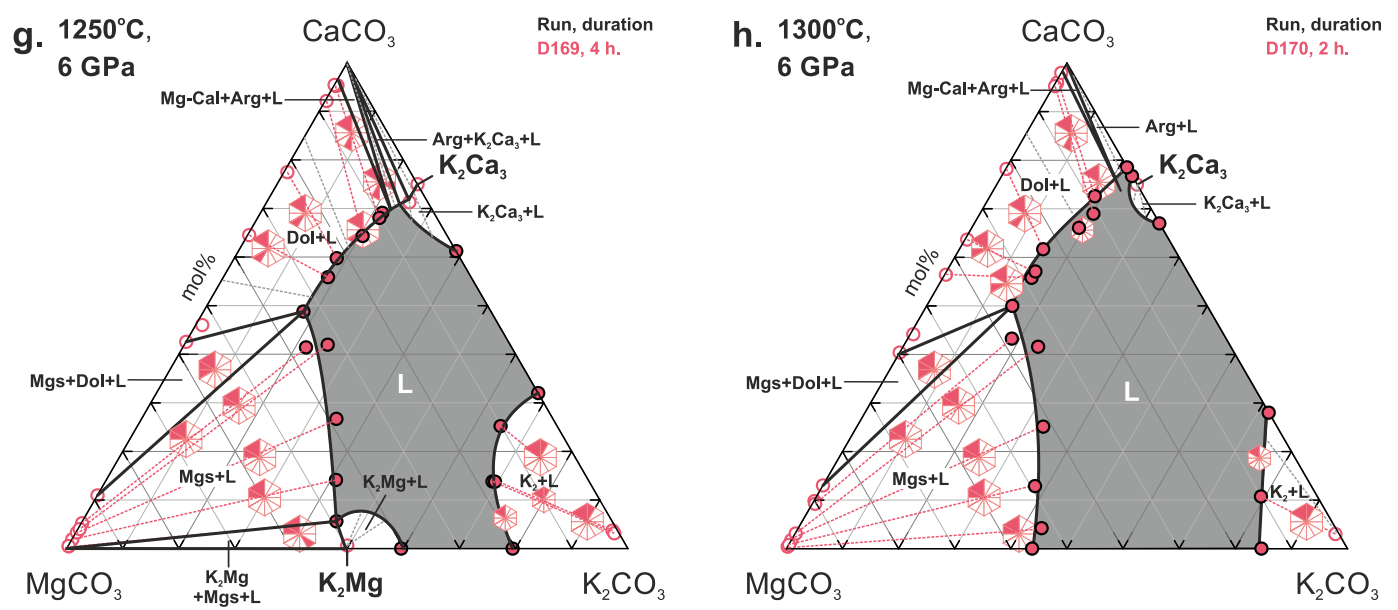

Figure 5. Isothermal sections of the $\mathrm{K}_{2} \mathrm{CO}_{3}-\mathrm{MgCO}_{3}-\mathrm{CaCO}_{3} \mathrm{~T}-X$ diagram at $6 \mathrm{GPa}$. (a) $900{ }^{\circ} \mathrm{C}$, (b) $1000{ }^{\circ} \mathrm{C}$, (c) $1080{ }^{\circ} \mathrm{C}$, (d) $1080<\mathrm{T}<1100{ }^{\circ} \mathrm{C}$ (inferred), (e) $1100{ }^{\circ} \mathrm{C}$, (f) $1200{ }^{\circ} \mathrm{C}$, (g) $1250{ }^{\circ} \mathrm{C}$, (h) 1300 ${ }^{\circ} \mathrm{C} . \mathrm{K}_{2}=\mathrm{K}_{2} \mathrm{CO}_{3}, \mathrm{~K}_{8} \mathrm{Ca}_{3}=\mathrm{K}_{8} \mathrm{Ca}_{3}\left(\mathrm{CO}_{3}\right)_{7}(\mathrm{Ca \#} \geq 97), \mathrm{K}_{2} \mathrm{Ca}=\mathrm{K}_{2}(\mathrm{Ca}, \mathrm{Mg})\left(\mathrm{CO}_{3}\right)_{2}(\mathrm{Ca \#} \geq 51), \mathrm{K}_{2} \mathrm{Ca}_{3}=$ $\mathrm{K}_{2} \mathrm{Ca}_{3}\left(\mathrm{CO}_{3}\right)_{4}(\mathrm{Ca \#} \geq 93), \mathrm{K}_{2} \mathrm{Mg}=\mathrm{K}_{2} \mathrm{Mg}\left(\mathrm{CO}_{3}\right)_{2}(\mathrm{Ca \#} \leq 42), \mathrm{Arg}=$ aragonite, Ca-Dol = Ca-rich dolomite, $\mathrm{Dol}=$ dolomite, $\mathrm{Mg}$-Cal $=\mathrm{Mg}$-bearing calcite, $\mathrm{Mgs}=$ magnesite, $\mathrm{L}=$ liquid . Colored marks denote different runs shown in the upper-right corner of each isothermal section. Open and filled circles indicate the compositions of solid and liquid phases measured by EDS. Filled segments in hexagons denote phases present. Yellow segments indicate the phases appearing in the LT side.

\section{Discussion}

\subsection{Comparison with the Previous Study}

Shatskiy et al. [33] determined the phase relations along the $\mathrm{K}_{2} \mathrm{CO}_{3}-\mathrm{Ca}_{0.5} \mathrm{Mg}_{0.5} \mathrm{CO}_{3}$ join at $6 \mathrm{GPa}$ using an experimental and analytical technique similar to the present study. Although a number of experimental points in their study were very limited, they succeeded to infer a few phase fields, Arg $+\mathrm{K}_{2} \mathrm{Mg}, \mathrm{K}_{2} \mathrm{Mg}+\mathrm{K}_{2}, \mathrm{Mgs}+\mathrm{K}_{2} \mathrm{Mg}$, and $\mathrm{Arg}+\mathrm{K}_{2} \mathrm{Mg}+\mathrm{Mgs}$ at $900{ }^{\circ} \mathrm{C}$ (Figure 3a in their study) like those established in the present study (Figure 5a). They also observed two distinct compositions of the $\mathrm{K}_{2}(\mathrm{Mg}, \mathrm{Ca})\left(\mathrm{CO}_{3}\right)_{2}$ compound with Ca\# of $\sim 10$ and $50-58$ and interpreted them as solid solution series, i.e., as a single phase (Figure $3 a$ in their study). Yet, based on the present results these compounds are immiscible under the specified $P-T$ conditions (Figure $5 \mathrm{a}$ ).

They also found two minima on the liquidus surface (Figure 3a in their study), whose compositions resemble those established in the present study, and succeeded to establish the $\mathrm{Mgs}+\mathrm{L}, \mathrm{K}_{2} \mathrm{Mg}+\mathrm{Mgs}$ $+\mathrm{L}$, and $\mathrm{K}_{2} \mathrm{Mg}+\mathrm{L}$ fields (Figure $3 \mathrm{~b}$ in their study) (Figure $5 \mathrm{~b}$ ). Given the temperature step of $100{ }^{\circ} \mathrm{C}$ in both studies, slightly lower minimum melting temperatures, $1000{ }^{\circ} \mathrm{C}$ instead of $1080^{\circ} \mathrm{C}$ in the present study, is not surprising.

The experimental points obtained by Shatskiy et al. [33] at 1100 and $1200{ }^{\circ} \mathrm{C}$ (Figure 3c,d in their study) are in reasonable agreement with those obtained in the present study (Figure $5 \mathrm{e}, \mathrm{f}$ ). The difference in some details of their interpretation is rather associated with an insufficient number of experimental points in their study [33] than with the inconsistency in the experimental data. For instance, Shatskiy, et al. [33] have interpreted the first melt [ $\left.36 \mathrm{~K}_{2} \mathrm{CO}_{3} \cdot 64\left(\mathrm{Ca}_{0.65} \mathrm{Mg}_{0.35}\right) \mathrm{CO}_{3}\right]$, found in coexistence with $\mathrm{Mgs}$ and $\mathrm{K}_{2} \mathrm{Mg}$ at $1000{ }^{\circ} \mathrm{C}$ as a eutectics. However, according to present results, the melt with such composition and coexisting phases is generated by peritectic reaction 5 ( $\mathrm{P}^{1}$ in Figure 6 ).

\subsection{Effect of Pressure}

Under mantle pressures and temperatures, the $\mathrm{K}_{2} \mathrm{CO}_{3}-\mathrm{CaCO}_{3}-\mathrm{MgCO}_{3}$ system (KCM) forms several intermediate compounds represented by alkali-alkaline earth double carbonates. At $3 \mathrm{GPa}$ and $750{ }^{\circ} \mathrm{C}$, these carbonates are represented by the low-pressure phases including $\mathrm{K}_{2} \mathrm{Mg}\left(\mathrm{CO}_{3}\right)_{2}$, $\mathrm{K}_{2} \mathrm{Ca}_{2}\left(\mathrm{CO}_{3}\right)_{2}$, and $\mathrm{K}_{2} \mathrm{Ca}\left(\mathrm{CO}_{3}\right)_{2}$ bütschliite $[37,39,40]$ (Figure $7 \mathrm{a}, \mathrm{b}$ ), which are also stable at ambient 
pressure [41-43]. At $6 \mathrm{GPa}, \mathrm{K}_{2} \mathrm{Mg}$ remains stable up to $1250{ }^{\circ} \mathrm{C}$, where it melts congruently [40], while the stability field of $\mathrm{K}_{2} \mathrm{Ca}$ is limited by $\sim 990^{\circ} \mathrm{C}$ for the pure endmember (Figure 6) [39] and $\sim 1050{ }^{\circ} \mathrm{C}$ for the Mg-bearing compound (Figure $5 \mathrm{~d}, \mathrm{c}$ ). The decomposition of $\mathrm{K}_{2} \mathrm{Ca}$ yields formation of high-pressure carbonates including $\mathrm{K}_{8} \mathrm{Ca}_{3}+\mathrm{K}_{2} \mathrm{Ca}_{3} \pm \mathrm{K}_{2} \mathrm{Mg}$ (Figure $7 \mathrm{~d}$ ). Thus, at $6 \mathrm{GPa}$ and $1080{ }^{\circ} \mathrm{C}$, the intermediate compounds are represented by $\mathrm{K}_{2} \mathrm{Mg}, \mathrm{K}_{2} \mathrm{Ca}_{3}, \mathrm{~K}_{8} \mathrm{Ca}_{3}$, and Dol (Figure 5d).

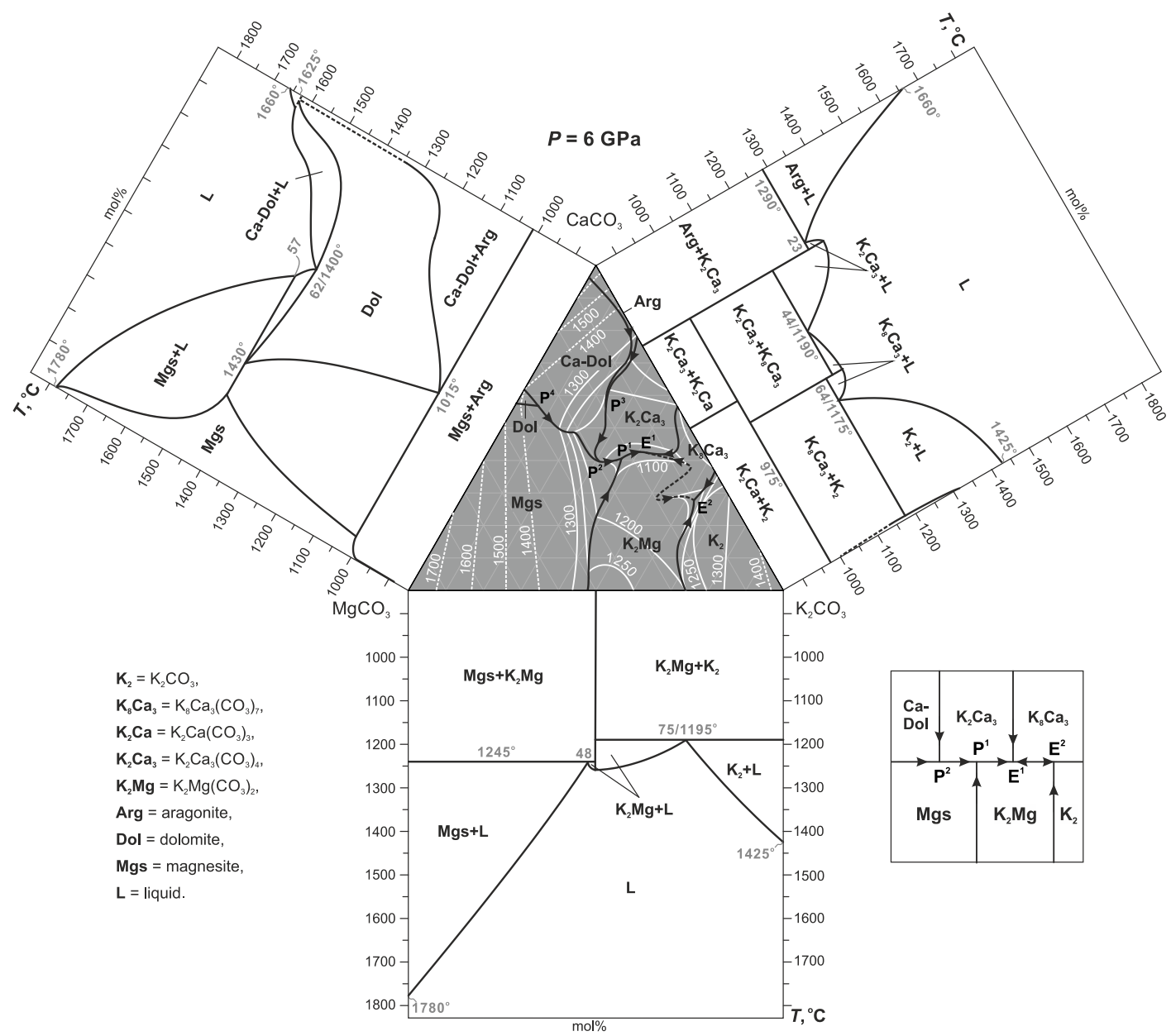

Figure 6. Liquidus phase relations in the system $\mathrm{K}_{2} \mathrm{CO}_{3}-\mathrm{MgCO}_{3}-\mathrm{CaCO}_{3}$ at $6 \mathrm{GPa}$. Black are boundary lines and white lines are liquidus isotherms with temperatures in degrees Celsius. Dashed lines were inferred. The phase relations in the corresponding binaries are from $[35,36,38,43]$. The relative position of peritectic and eutectic points is shown on the schematic sketch at the right-bottom. See the Nomenclature section for abbreviations.

At $3 \mathrm{GPa}$, the diagram has one minimum on the liquidus surface, which is a $\mathrm{K}_{2}-\mathrm{K}_{2} \mathrm{Mg}-\mathrm{K}_{2} \mathrm{Ca}$ ternary eutectic located at $53 \mathrm{~K}_{2} \mathrm{CO}_{3} \cdot 47 \mathrm{Ca}_{0.4} \mathrm{Mg}_{0.6} \mathrm{CO}_{3}$ and $\sim 825^{\circ} \mathrm{C}$ (Figures $7 \mathrm{~b}$ and $8 \mathrm{a}$ ). The present study showed that at $6 \mathrm{GPa}$, the system has two minima corresponding to $\mathrm{K}_{2} \mathrm{Ca}_{3}-\mathrm{K}_{8} \mathrm{Ca}_{3}-\mathrm{K}_{2} \mathrm{Mg}$ and $\mathrm{K}_{8} \mathrm{Ca}_{3}-\mathrm{K}_{2}-\mathrm{K}_{2} \mathrm{Mg}$ eutectics at $40 \mathrm{~K}_{2} \mathrm{CO}_{3} \cdot 60\left(\mathrm{Ca}_{0.70} \mathrm{Mg}_{0.30}\right) \mathrm{CO}_{3}$ and $62 \mathrm{~K}_{2} \mathrm{CO}_{3} \cdot 38\left(\mathrm{Ca}_{0.73} \mathrm{Mg}_{0.27}\right) \mathrm{CO}_{3}$, respectively. Both are located at $1090{ }^{\circ} \mathrm{C}$ (Figures $7 \mathrm{~d}$ and $8 \mathrm{~b}$ ). See the Nomenclature section for abbreviations.

\subsection{Comparison with the Na-Bearing System}

Similar to $\mathrm{KCM}$ at $6 \mathrm{GPa}$, the $\mathrm{Na}_{2} \mathrm{CO}_{3}-\mathrm{CaCO}_{3}-\mathrm{MgCO}_{3}$ system (NCM) forms several intermediate compounds including Dol, $\mathrm{Na}_{2} \mathrm{Ca}_{4}, \mathrm{Na}_{2} \mathrm{Ca}_{3}, \mathrm{Na}_{4} \mathrm{Ca}$, and $\mathrm{Na}_{2} \mathrm{Mg}$ [44]. The first melting occurs at $1050{ }^{\circ} \mathrm{C}$, which is close to that in $\mathrm{KCM}\left(1090^{\circ} \mathrm{C}\right)$. In contrast to $\mathrm{KCM}$ (Figure $8 \mathrm{~b}$ ), which has two eutectics, NCM has a single eutectic, $\mathrm{Na}_{2} \mathrm{Ca}_{3}-\mathrm{Na}_{4} \mathrm{Ca}-\mathrm{Na}_{2} \mathrm{Mg}$, with a composition of $48 \mathrm{Na}_{2} \mathrm{CO}_{3} \cdot 52\left(\mathrm{Ca}_{0.75} \mathrm{Mg}_{0.25}\right) \mathrm{CO}_{3}$ 
(Figure 8d). As pressure decreases to $3 \mathrm{GPa}$, the incipient melting of $\mathrm{NCM}$ shifts to $850{ }^{\circ} \mathrm{C}$ and controlled by the $\mathrm{Na}_{2} \mathrm{Ca}+\mathrm{Na}_{2}+\mathrm{Na}_{2} \mathrm{Mg}$ assemblage [45], similar to the $\mathrm{K}_{2} \mathrm{Ca}-\mathrm{K}_{2}-\mathrm{K}_{2} \mathrm{Mg}$ eutectic established in $\mathrm{KCM}$ at $3 \mathrm{GPa}$ and $825^{\circ} \mathrm{C}$ [37] (Figure 8a,c). The difference is that the KCM eutectic is $\mathrm{Mg}$-rich, $53 \mathrm{~K}_{2} \mathrm{CO}_{3} \cdot 47 \mathrm{Ca}_{0.4} \mathrm{Mg}_{0.6} \mathrm{CO}_{3}$, while the $\mathrm{NCM}$ eutectic is Ca-rich with compositions of $52 \mathrm{Na}_{2} \mathrm{CO}_{3} \cdot 48 \mathrm{Ca}_{0.62} \mathrm{Mg}_{0.38} \mathrm{CO}_{3}$ (Figure $8 \mathrm{a}, \mathrm{c}$ ).

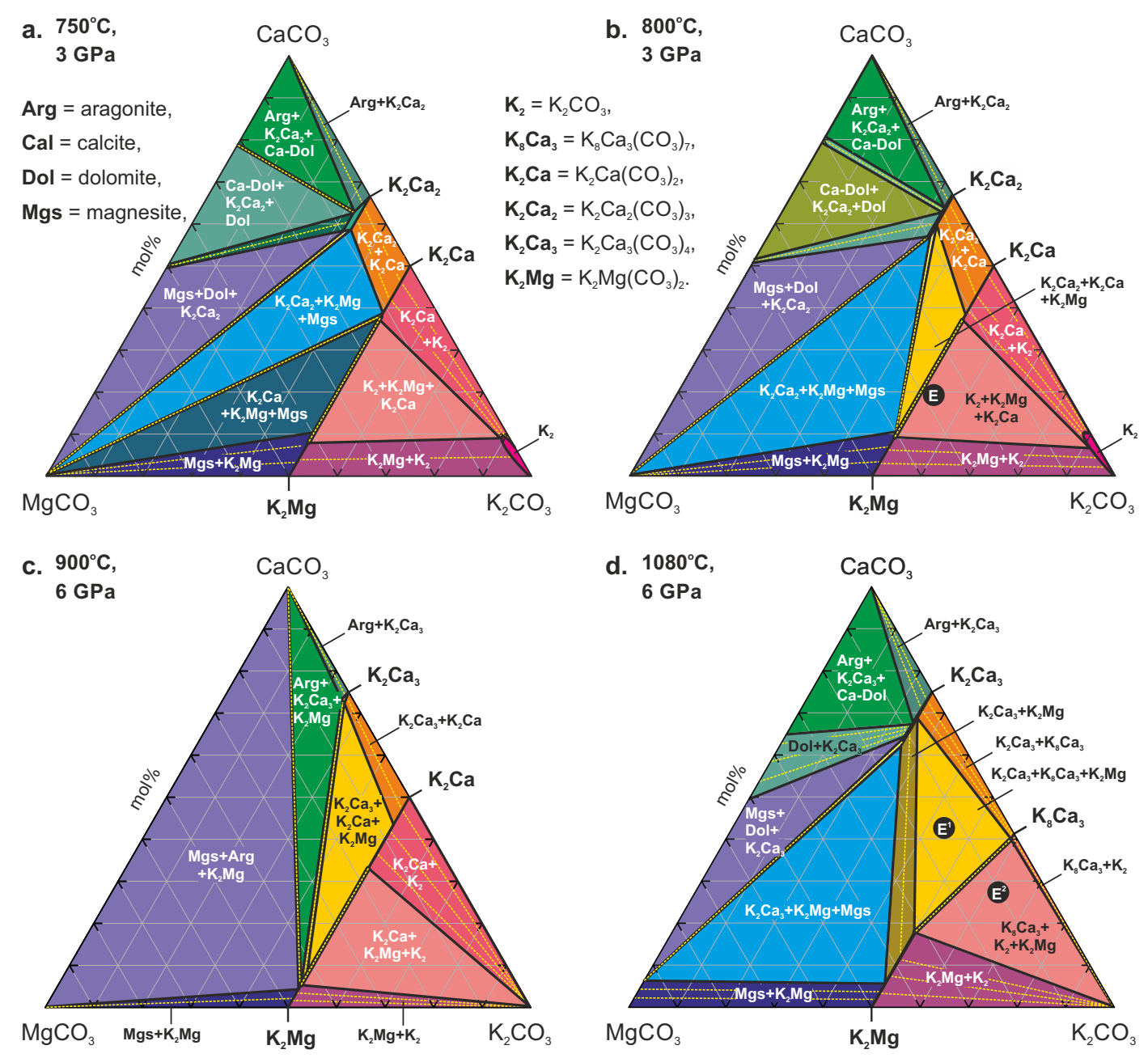

Figure 7. Isothermal and isobaric sections of the $\mathrm{K}_{2} \mathrm{CO}_{3}-\mathrm{CaCO}_{3}-\mathrm{MgCO}_{3} \mathrm{~T}$-X diagram at $3 \mathrm{GPa}, 750{ }^{\circ} \mathrm{C}$ (a) and $800{ }^{\circ} \mathrm{C}(\mathbf{b})$ [37] and at $6 \mathrm{GPa}, 900{ }^{\circ} \mathrm{C}$ (c) and $1080{ }^{\circ} \mathrm{C}$ (d) (this study). E, $\mathrm{E}^{1}$, and $\mathrm{E}^{2}$ denote corresponding eutectic points. See the Nomenclature section for abbreviations.

\subsection{Mutual Solubility of $\mathrm{K}_{2} \mathrm{Ca}\left(\mathrm{CO}_{3}\right)_{2}$ and $\mathrm{K}_{2} \mathrm{Mg}\left(\mathrm{CO}_{3}\right)_{2}$}

Carbonate with the $\mathrm{K}_{2} \mathrm{Mg}\left(\mathrm{CO}_{3}\right)_{2}$ stoichiometry was first synthesized at $4 \mathrm{MPa}$ [46] and then was also obtained under the upper mantle and even transitions zone $P-T$ conditions $[32,36,40,47]$. The crystal structure analysis performed at ambient conditions revealed that $\mathrm{K}_{2} \mathrm{Mg}\left(\mathrm{CO}_{3}\right)_{2}$ is isostructural to $\mathrm{K}_{2} \mathrm{Ca}\left(\mathrm{CO}_{3}\right)_{2}$ bütschliite [48] and has the rhombohedral symmetry with the space group $R \overline{3} m$ [49]. In situ X-ray diffraction study revealed that $\mathrm{K}_{2} \mathrm{Mg}\left(\mathrm{CO}_{3}\right)_{2}$ retains its structure to $8 \mathrm{GPa}$ upon compression at the ambient temperature where it transforms into a monoclinic polymorph [50]. However, the present results at $6 \mathrm{GPa}$ and the results at $3 \mathrm{GPa}$ [37] show a miscibility gap on the $\mathrm{K}_{2} \mathrm{Ca}\left(\mathrm{CO}_{3}\right)_{2}-\mathrm{K}_{2} \mathrm{Mg}\left(\mathrm{CO}_{3}\right)_{2}$ join (Figure 7a-c). This suggests that crystal structures of $\mathrm{K}_{2} \mathrm{Mg}\left(\mathrm{CO}_{3}\right)_{2}$ and $\mathrm{K}_{2} \mathrm{Ca}\left(\mathrm{CO}_{3}\right)_{2}$ at 3-6 $\mathrm{GPa}$ and $750-1000{ }^{\circ} \mathrm{C}$ are different. Indeed, X-ray diffraction patterns taken from $\mathrm{K}_{2} \mathrm{Mg}\left(\mathrm{CO}_{3}\right)_{2}$ in situ in $\mathrm{HP}-\mathrm{HT}$ experiments revealed that the crystal structure of $\mathrm{K}_{2} \mathrm{Mg}\left(\mathrm{CO}_{3}\right)_{2}$ at $6.5 \mathrm{GPa}$ and $1000{ }^{\circ} \mathrm{C}$ and at $1.1 \mathrm{GPa}$ and $400^{\circ} \mathrm{C}$ differs from bütschliite [36]. 

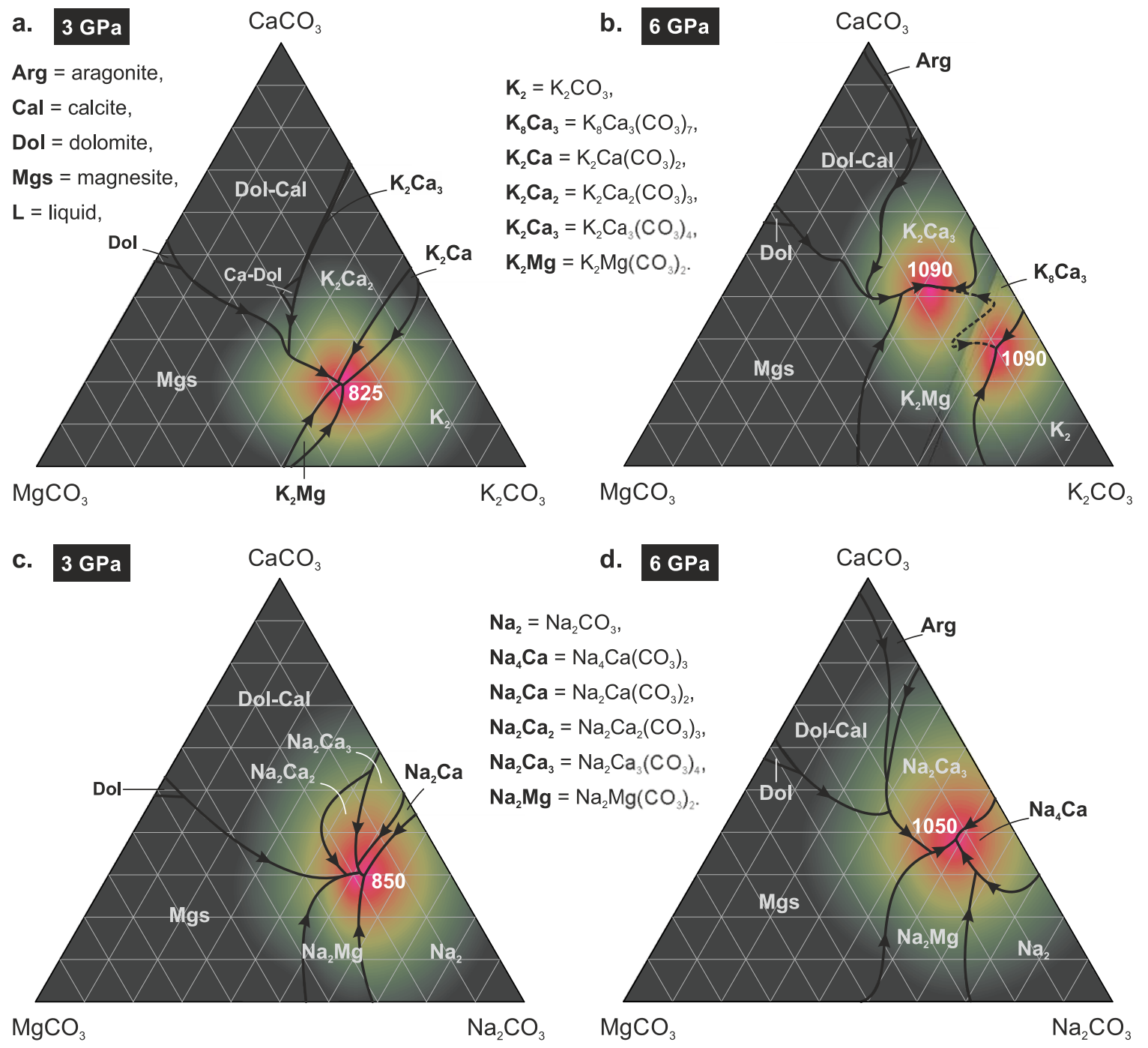

Figure 8. The diagrams illustrating primary crystallization regions and ternary eutectics in the system $\mathrm{K}_{2} \mathrm{CO}_{3}-\mathrm{CaCO}_{3}-\mathrm{MgCO}_{3}$ at $3 \mathrm{GPa}$ (a) [37] and at $6 \mathrm{GPa}$ (b) (this study) and in the system $\mathrm{Na}_{2} \mathrm{CO}_{3}-\mathrm{CaCO}_{3}-\mathrm{MgCO}_{3}$ at $3 \mathrm{GPa}$ (c) [45] and at $6 \mathrm{GPa}$ (d) [44]. $\mathrm{Na}_{2}-\mathrm{Na}_{2} \mathrm{CO}_{3}, \mathrm{Na}_{2} \mathrm{Ca}_{2}-\mathrm{Na}_{2} \mathrm{Ca}_{2}\left(\mathrm{CO}_{3}\right)_{3}$, $\mathrm{Na}_{2} \mathrm{Ca}_{3}-\mathrm{Na}_{2} \mathrm{Ca}_{3}\left(\mathrm{CO}_{3}\right)_{4}, \mathrm{Na}_{2} \mathrm{Mg}-\mathrm{Na}_{2} \mathrm{Mg}\left(\mathrm{CO}_{3}\right)_{2}$, see the Nomenclature section for other abbreviations.

\subsection{Variety of Carbonates in Diamonds and Their Origin}

A wide range of carbonates has been detected among inclusions in diamonds: magnesite $[7,8]$, dolomite [9,11,24,51], calcite [6,11], aragonite [12], siderite [52], and various alkali-bearing double carbonates: $\mathrm{K}_{2} \mathrm{Ca}\left(\mathrm{CO}_{3}\right)_{2}$ bütschliite [27], $\mathrm{K}_{2}\left(\mathrm{Mg}_{0.9-0.5} \mathrm{Ca}_{0.1-0.5}\right)\left(\mathrm{CO}_{3}\right)_{2}$ [28], $(\mathrm{Na}, \mathrm{K})_{2} \mathrm{Ca}\left(\mathrm{CO}_{3}\right)_{2}$ nyerereite [53], and $\mathrm{Na}_{2} \mathrm{Mg}\left(\mathrm{CO}_{3}\right)_{2}$ eitelite $[54,55]$. The origin of carbonate minerals in the syngenetic inclusions in diamonds can be different. Some of them could be entrapped as minerals crystalized syngenetically with the host diamond from carbonatite melt. Others could be the daughter phases, precipitated from the entrapped melt during kimberlite magma emplacement and cooling. Below, we discuss a possible origin of various carbonate minerals found in diamonds considering the established phase relations in KCM and NCM systems.

It is generally accepted that most diamonds were crystallized at the base of ancient cratons at 5-7 GPa and $900-1400{ }^{\circ} \mathrm{C}[56]$ since Archean, whereas the carbonatitic melts are considered as the most probable carbon source and medium for their crystallization $[27,28,57,58]$, while other media for diamond crystallization are also known [59-63]. 
The melting along the $\mathrm{CaCO}_{3}-\mathrm{MgCO}_{3}$ join extends from $1660^{\circ} \mathrm{C}\left(\mathrm{CaCO}_{3}\right)$ to $1780{ }^{\circ} \mathrm{C}\left(\mathrm{MgCO}_{3}\right)$ through a minimum at $1400{ }^{\circ} \mathrm{C}$ and $62 \mathrm{~mol}^{\circ} \mathrm{CaCO}_{3}$ [35] (Figure 6). Consequently, monomineralic inclusions of $\mathrm{MgCO}_{3}, \mathrm{CaCO}_{3}$, and $\mathrm{CaMg}\left(\mathrm{CO}_{3}\right)_{2}$ in diamonds must be entrapped as minerals, because their melting points exceed the growth temperatures of most lithospheric diamonds (Figure 9).

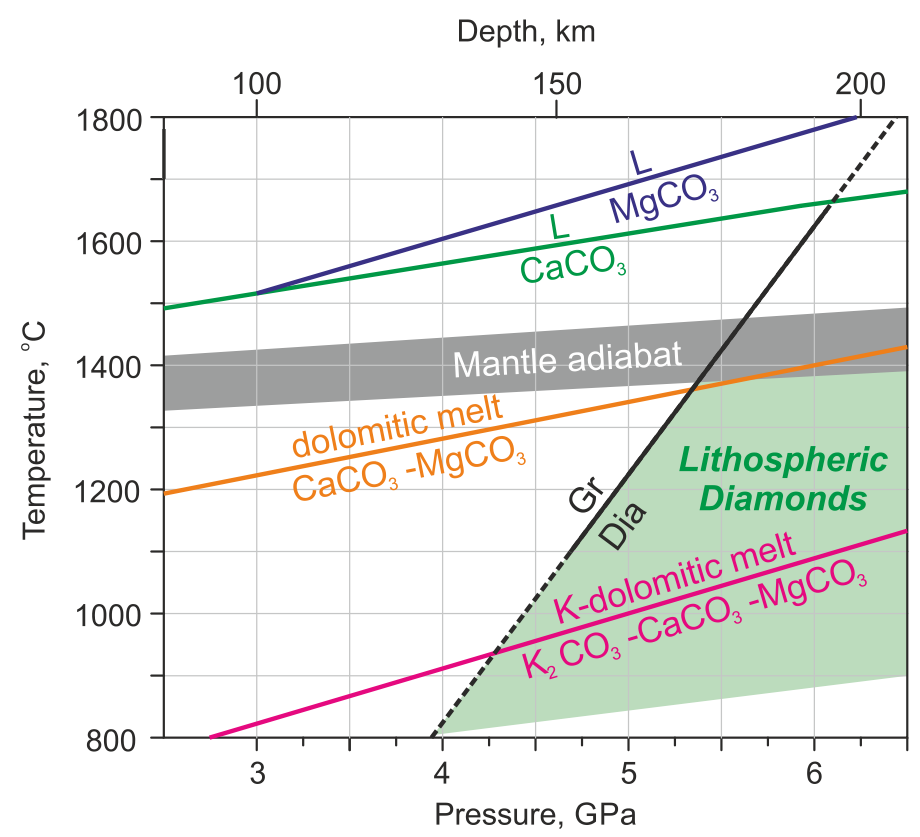

Figure 9. $P-T$ plot illustrating solidus of the $\mathrm{K}_{2} \mathrm{CO}_{3}-\mathrm{CaCO}_{3}-\mathrm{MgCO}_{3}$ and $\mathrm{CaCO}_{3}-\mathrm{MgCO}$ systems and melting curves of $\mathrm{CaCO}_{3}$ and $\mathrm{MgCO}_{3}$ [35] compared with mantle adiabat [64] and $P-T$ range of diamond growth in the lithospheric mantle [56]. Gr/Dia-the equilibrium boundary between diamond and graphite [65].

Jablon and Navon [28] discovered K-rich carbonate inclusions of a few hundred nanometers in size entrapped along the twining plane of macles formed by clear octahedral diamond crystals. The electron probe micro-analyzer (EPMA) revealed that some of these inclusions resemble $\mathrm{K}_{2}(\mathrm{Mg}, \mathrm{Ca})\left(\mathrm{CO}_{3}\right)_{2}$ with Ca\# $=20-43$. Our results suggest that these inclusions could be formed in the diamond stability field because at lower pressure, the $\mathrm{K}_{2} \mathrm{Ca}\left(\mathrm{CO}_{3}\right)_{2}$ solubility in the $\mathrm{K}_{2}(\mathrm{Mg}, \mathrm{Ca})\left(\mathrm{CO}_{3}\right)_{2}$ decreases [37]. The temperature of the entrapment has to be restricted by $1100{ }^{\circ} \mathrm{C}$ because at $100{ }^{\circ} \mathrm{C}$ higher and lower temperatures the $\mathrm{K}_{2} \mathrm{Ca}\left(\mathrm{CO}_{3}\right)_{2}$ content decreases below 10-20 mol\% (Figure $5 \mathrm{~b}$,f and Tables S2, S6 and S7). Thus, the Ca\# of about 40 of the $\mathrm{K}_{2}(\mathrm{Mg}, \mathrm{Ca})\left(\mathrm{CO}_{3}\right)_{2}$ compound found as single-phase inclusions in diamond implies that its crystallization under the $P-T$ conditions of $6 \mathrm{GPa}$ and $1100{ }^{\circ} \mathrm{C}$, corresponding to the base of the continental lithospheric mantle. However, the further entrapment of diamond by the hot kimberlite magma $\left(1400-1500^{\circ} \mathrm{C}\right)[66,67]$ implies the remelting of the $\mathrm{K}_{2}(\mathrm{Mg}, \mathrm{Ca})\left(\mathrm{CO}_{3}\right)_{2}$ compound and its repeated crystallization during kimberlite magma emplacement.

Logvinova et al. [27] identified $\mathrm{K}_{2} \mathrm{Ca}\left(\mathrm{CO}_{3}\right)_{2}$ bütschliite within $30 \mu \mathrm{m}$ carbonate inclusion in a gem-quality octahedral diamond crystal from Sytykanskaya kimberlite pipe (Yakutia). Bütschliite was found in coexistence with dolomite and $\mathrm{Na}_{2} \mathrm{Mg}\left(\mathrm{CO}_{3}\right)_{2}$ eitelite. The present results on $\mathrm{KCM}$ (Figure 5a,b) and data on NCM [44,45] indicate that neither bütschliite nor eitelite can coexist with dolomite under the $P-T$ conditions of diamond crystallization in the lithospheric mantle (Figure 5). This led to the conclusion that at the time of entrapment, the inclusion material was an alkali-bearing dolomitic melt and that bütschliite is a daughter phase [27].

Although high-pressure carbonates, $\mathrm{K}_{8} \mathrm{Ca}_{3}\left(\mathrm{CO}_{3}\right)_{7}$ and $\mathrm{K}_{2} \mathrm{Ca}_{3}\left(\mathrm{CO}_{3}\right)_{4}$ have not yet been found in diamonds, their high melting points, $>1200$ and $>1300{ }^{\circ} \mathrm{C}$, respectively, do not exclude the possibility of their co-crystallization with diamond and their entrapment as mono- and polymineral inclusions (Figure 6). 


\subsection{Thermal Stability of Carbonatitic Melts vs. Alkalinity}

At $6 \mathrm{GPa}$, the $\mathrm{K}_{2} \mathrm{CO}_{3}-\mathrm{CaCO}_{3}-\mathrm{MgCO}_{3}$ system starts to melt near $1100{ }^{\circ} \mathrm{C}$ (Figure $8 \mathrm{~b}$ ). This temperature corresponds to the majority of the temperature estimations for peridotitic and eclogitic diamonds [56] and coincides with the continental geotherm with the heat flow of $35 \mathrm{~mW} / \mathrm{m}^{2}$ [68]. The present results suggest that under the $P-T$ conditions of the continental lithosphere $\left(1100-1200{ }^{\circ} \mathrm{C}\right.$ at $6 \mathrm{GPa}$ corresponding to a depth of $200 \mathrm{~km}$ ), the carbonatitic melt must be alkali-rich. This is consistent with the potassium-rich composition of the most carbonatitic micro inclusions in natural diamonds (Figure 10).

a.

$\mathrm{CaCO}_{3}$

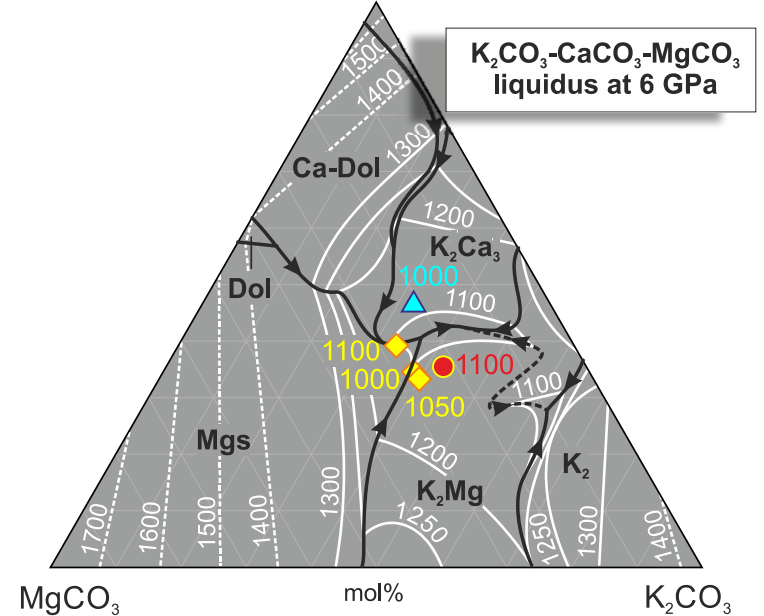

$(\mathrm{Mg}, \mathrm{Fe}) \mathrm{CO}_{3}$

Pelite-derived carbonatitic melts:

DG2, $1100^{\circ} \mathrm{C} / 8 \mathrm{GPa}$ (GS11)

HPLC4, $1000^{\circ} \mathrm{C} / 5 \mathrm{GPa}(\mathrm{T} 12)$

$\mathrm{DG} 2,1000-1100^{\circ} \mathrm{C} / 6 \mathrm{GPa}(\mathrm{S} 19)$

$(\mathrm{K}, \mathrm{Na})_{2} \mathrm{CO}_{3}$ b.

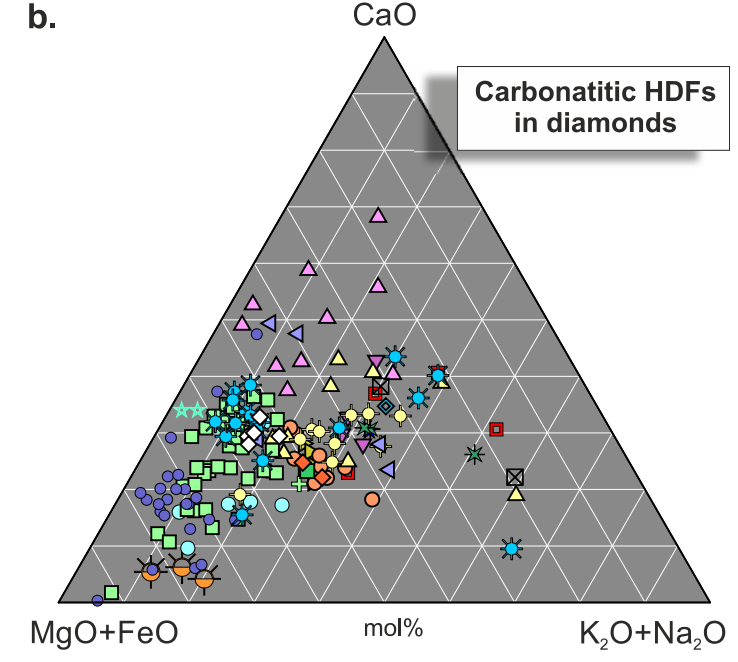

Carbonatitic HDFs in diamonds worldwide:

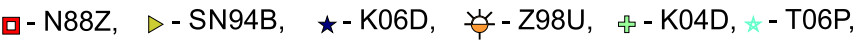

*-K07D, O-Z07U, $\nabla-\mathrm{K} 09 \mathrm{~A}, \diamond-\mathrm{K} 09 \mathrm{~K}, \diamond-\mathrm{K} 09 \mathrm{Z}, \Delta$-W09K,

○-K09U, 口-K09Y, 口-Z09I, -K10C, ०-S11I, $\Delta$-Z11E,

$\triangleleft-\mathrm{S} 12 \mathrm{~S}, \quad \nabla-\mathrm{W} 14 \mathrm{~F},-\mathrm{JN16VV}, \diamond-\mathrm{S} 16 \mathrm{M}$

Figure 10. Comparison of the liquidus relationships established in the $\mathrm{K}_{2} \mathrm{CO}_{3}-\mathrm{CaCO}_{3}-\mathrm{MgCO}_{3}$ system with the compositions of pelite-derived melts (a) and carbonatitic HDFs in diamonds worldwide (b). N88Z_fibrous (cubic and coated octahedral) diamonds from Zaire and Botswana [18]; SN94B_fibrous diamonds with cubic morphology from Jwaneng, Botswana [19]; Z98U-K-Cr-rich aluminosilicate melt inclusions (up to $150 \mu \mathrm{m}$ in size) in 'monocrystalline' octahedral diamonds of peridotitic suite from Udachnaya kimberlite pipe [69], K04D—a coated diamond from the Diavik mine in Canada containing peridotitic minerals [70]; K06D—fibrous (cubic and coated octahedral) diamonds from the Diavik mine in Canada and the Yubileinaya mine in Russia [71]; T06P_coated diamonds (eclogitic and peridotitic) from the Panda kimberlite in Canada [25]; K07D-fibrous diamonds from the Diavik mine, Canada [72]; Z07U—cuboid fibrous diamonds from the Udachnaya kimberlite, Russia [73]; K09A, K09K, K09U, K09Y, K09Z-fibrous diamonds with cubic morphology from the Aykhal Komsomolskaya, Udachnaya, Yubileinaya, Zarnitsa kimberlite pipes, Russia [21]; W09K—coated octahedral diamonds from Kankan, Guinea [22]; Z09I—cuboid diamonds with fibrous inner zone from Internatsional'naya kimberlite pipe, Russia [20]; S11I—cloudy diamonds from the Internatsional'naya pipe, Russia [74]; Z11E-fibrous diamonds with cubic and semi rounded morphology from the Ebelyakh River placer deposits, Russia [75]; S12S-fibrous diamonds from the 2.701-2.697 Ga Wawa metaconglomerate, Canada [76]; W14F — a coated diamond from Finch mine, South Africa [77]. JN16VV—along (111) twinning surfaces in 'monocrystalline' octahedral diamonds of peridotitic suite from South Africa's Venetia and Voorspoed mines [28]; S16M—cloudy diamonds from the Mir kimberlite pipe, Russia [23].

In contrast to alkali-rich carbonates, alkali-poor carbonates do not experience a full melting under the $P-T$ conditions of the continental geotherm. The melting of Ca-Mg-Fe carbonates $[35,78,79]$ is possible under the temperatures of the convective mantle in asthenosphere, $1450-1500{ }^{\circ} \mathrm{C}$ at a depth 
of $200 \mathrm{~km}$ [64], or at the base of lithospheric mantle under 'kinked' geotherm $\left(\geq 1350^{\circ} \mathrm{C}\right)$ developed presumably due to mantle plume activity [80-83]. There is direct evidence of the formation of such melts, namely, kimberlite-associated diamondiferous magnesiocarbonatites [84].

\subsection{Daughter Carbonate Minerals, Which Can Be Expected in Diamond Inclusions}

Most of the carbonatitic inclusions in diamonds fall into the primary crystallization field of Mgs. Slow cooling of these inclusions, which could occur in hypabyssal conditions, should cause crystallization of Mgs. This shifts the residual melt composition toward the K-rich eutectic one $\left(\mathrm{E}^{1}\right)$ and yields precipitation of $\mathrm{K}_{2} \mathrm{Mg}+\mathrm{K}_{2} \mathrm{Ca}_{3}+\mathrm{K}_{8} \mathrm{Ca}_{3}$ at the final stage of crystallization (Figure 7d). If we consider a possible pressure drop upon cooling, the daughter phases may also include $\mathrm{K}_{2} \mathrm{Ca}_{2}, \mathrm{~K}_{2} \mathrm{Ca}$, and $\mathrm{K}_{2}$ (Figure $7 \mathrm{a}, \mathrm{b}$ ).

Explosive eruption of kimberlite magma implies a rapid cooling of diamonds and micro inclusions therein. In this case, the following assemblages of carbonate phases can be formed: $\mathrm{Mgs}+\mathrm{Arg}+\mathrm{K}_{2} \mathrm{Mg}$, $\operatorname{Arg}+\mathrm{K}_{2} \mathrm{Ca}_{3}+\mathrm{K}_{2} \mathrm{Mg}, \mathrm{K}_{2} \mathrm{Mg}+\mathrm{K}_{2} \mathrm{Ca}+\mathrm{K}_{2} \mathrm{Ca}_{3}$, and $\mathrm{K}_{2}+\mathrm{K}_{2} \mathrm{Mg}+\mathrm{K}_{2} \mathrm{Ca}$ (Figure 7c). A pressure drop upon cooling can also yield an appearance of the following assemblages $\mathrm{Mgs}+\mathrm{K}_{2} \mathrm{Ca}+\mathrm{K}_{2} \mathrm{Mg}$, $\mathrm{Mgs}+$ $\mathrm{K}_{2} \mathrm{Ca}+\mathrm{K}_{2} \mathrm{Ca}_{2}$, and $\mathrm{Mgs}+\mathrm{K}_{2} \mathrm{Ca}_{2}+\mathrm{Dol}$ (Figure 7a).

\subsection{Comparison with Carbonated Pelite-Derived Melts}

Neither peridotites nor eclogites with the natural abundance of $\mathrm{K}_{2} \mathrm{O}$ can yield formation of $\mathrm{K}$-rich melts [85-87]. On the other hand, partial melting of carbonated pelites at 5-8 GPa and 1000-1100 ${ }^{\circ} \mathrm{C}$ yields K-rich dolomitic melts [29-31], which resemble a minimum on the $\mathrm{K}_{2} \mathrm{CO}_{3}-\mathrm{CaCO}_{3}-\mathrm{MgCO}_{3}$ liquidus established in the present study (Figure 10a). This suggests that the melting behavior of the $\mathrm{KAlSi}_{3} \mathrm{O}_{8}-\mathrm{CaMg}\left(\mathrm{CO}_{3}\right)_{2}$ system, controlling carbonated pelite solidus, is essentially the same as that established here in the $\mathrm{K}_{2} \mathrm{CO}_{3}-\mathrm{CaCO}_{3}-\mathrm{MgCO}_{3}$ system at $6 \mathrm{GPa}$.

\section{Conclusions}

Phase relations in the $\mathrm{K}_{2} \mathrm{CO}_{3}-\mathrm{CaCO}_{3}-\mathrm{MgCO}_{3}$ system have been studied at $6 \mathrm{GPa}$ and $900-1300{ }^{\circ} \mathrm{C}$ using Kawai-type multianvil press. At the subsolidus conditions in experiments at 900 and $1000{ }^{\circ} \mathrm{C}$, three intermediate compounds $\mathrm{K}_{2} \mathrm{Ca}_{3}\left(\mathrm{CO}_{3}\right)_{4}$ (Ca\# $\left.\geq 97\right), \mathrm{K}_{2} \mathrm{Ca}\left(\mathrm{CO}_{3}\right)_{2}$ bütschliite (Ca\# $\geq 58$ ), and $\mathrm{K}_{2} \mathrm{Mg}\left(\mathrm{CO}_{3}\right)_{2}$ (Ca\# $\left.\leq 10\right)$ were established. A miscibility gap between $\mathrm{K}_{2} \mathrm{Ca}\left(\mathrm{CO}_{3}\right)_{2}$ and $\mathrm{K}_{2} \mathrm{Mg}\left(\mathrm{CO}_{3}\right)_{2}$ suggest that their crystal structures differ at $6 \mathrm{GPa}$. $\mathrm{K}_{2} \mathrm{Ca}\left(\mathrm{CO}_{3}\right)_{2}(\mathrm{Ca \#} \leq 28)$ disappear above $1000{ }^{\circ} \mathrm{C}$ to produce $\mathrm{K}_{2} \mathrm{Ca}_{3}\left(\mathrm{CO}_{3}\right)_{4}+\mathrm{K}_{8} \mathrm{Ca}_{3}\left(\mathrm{CO}_{3}\right)_{7}+\mathrm{K}_{2} \mathrm{Mg}\left(\mathrm{CO}_{3}\right)_{2}$.

The system has four ternary peritectic points and two minima on the liquidus at about $1090{ }^{\circ} \mathrm{C}$ corresponding to ternary eutectic points. The eutectics are controlled by the following melting reactions: $\mathrm{K}_{2} \mathrm{Ca}_{3}\left(\mathrm{CO}_{3}\right)_{4}+\mathrm{K}_{8} \mathrm{Ca}_{3}\left(\mathrm{CO}_{3}\right)_{7}+\mathrm{K}_{2} \mathrm{Mg}\left(\mathrm{CO}_{3}\right)_{2} \rightarrow\left[40 \mathrm{~K}_{2} \mathrm{CO}_{3} \cdot 60\left(\mathrm{Ca}_{0.70} \mathrm{Mg}_{0.30}\right) \mathrm{CO}_{3}\right]$ (1st eutectic melt) and $\mathrm{K}_{8} \mathrm{Ca}_{3}\left(\mathrm{CO}_{3}\right)_{7}+\mathrm{K}_{2} \mathrm{CO}_{3}+\mathrm{K}_{2} \mathrm{Mg}\left(\mathrm{CO}_{3}\right)_{2} \rightarrow\left[62 \mathrm{~K}_{2} \mathrm{CO}_{3} \cdot 38\left(\mathrm{Ca}_{0.73} \mathrm{Mg}_{0.27}\right) \mathrm{CO}_{3}\right]$ (2nd eutectic melt). The peritectic points are controlled by the following reactions: $\mathrm{K}_{2} \mathrm{Ca}_{3}\left(\mathrm{CO}_{3}\right)_{4}+\mathrm{K} 2 \mathrm{Mg}\left(\mathrm{CO}_{3}\right)_{2} \rightarrow \mathrm{Mgs}$ + liquid $\left(\mathrm{P}^{1}\right)$, at $1075 \pm 25^{\circ} \mathrm{C} ; \mathrm{K}_{2} \mathrm{Ca}_{3}\left(\mathrm{CO}_{3}\right)_{4}+$ magnesite $\rightarrow \mathrm{Ca}-\mathrm{Dol}+$ liquid $\left(\mathrm{P}^{2}\right)$, at $1150 \pm 50{ }^{\circ} \mathrm{C}$; $\mathrm{K}_{2} \mathrm{Ca}_{3}\left(\mathrm{CO}_{3}\right)_{4}+$ Ca-dolomite $\rightarrow \operatorname{Arg}+\operatorname{liquid}\left(\mathrm{P}^{3}\right)$, at $1150 \pm 50^{\circ} \mathrm{C}$; Ca-dolomite + magnesite $\rightarrow$ dolomite + liquid $\left(\mathrm{P}^{4}\right)$, at $1350 \pm 50^{\circ} \mathrm{C}$.

The liquidus projection of the studied ternary system has eight primary crystallization phase regions for magnesite, aragonite, dolomite, Ca-dolomite, $\mathrm{K}_{2} \mathrm{Ca}_{3}\left(\mathrm{CO}_{3}\right)_{4}, \mathrm{~K}_{8} \mathrm{Ca}_{3}\left(\mathrm{CO}_{3}\right)_{7}, \mathrm{~K}{ }_{2} \mathrm{Mg}\left(\mathrm{CO}_{3}\right)_{2}$ and $\mathrm{K}_{2} \mathrm{CO}_{3}$. The temperature increase is accompanied by the sequential disappearance of crystalline phases in the following sequence: $\mathrm{K}_{8} \mathrm{Ca}_{3}\left(\mathrm{CO}_{3}\right)_{7}\left(1220^{\circ} \mathrm{C}\right) \rightarrow \mathrm{K}_{2} \mathrm{Mg}\left(\mathrm{CO}_{3}\right)_{2}\left(1250^{\circ} \mathrm{C}\right) \rightarrow \mathrm{K}_{2} \mathrm{Ca}_{3}\left(\mathrm{CO}_{3}\right)_{4}$ $\left(1350{ }^{\circ} \mathrm{C}\right) \rightarrow \mathrm{K}_{2} \mathrm{CO}_{3}\left(1425^{\circ} \mathrm{C}\right) \rightarrow$ dolomite $\left(1450^{\circ} \mathrm{C}\right) \rightarrow \mathrm{CaCO}_{3}\left(1660^{\circ} \mathrm{C}\right) \rightarrow$ magnesite $\left(1780{ }^{\circ} \mathrm{C}\right)$.

The high alkali content in the carbonate melt is a necessary condition for its existence under geothermal conditions of the continental lithosphere. The obtained results indicate that at $6 \mathrm{GPa}$ and 1100-1200 ${ }^{\circ} \mathrm{C}$ corresponding to the base of the continental lithospheric mantle, the K-Ca-Mg carbonate melts must contain $20-40 \mathrm{~mol}^{2} \mathrm{~K}_{2} \mathrm{CO}_{3}$, otherwise, it will simply freeze. 
Supplementary Materials: Figure S1 and Tables S1-S10 are available online at http:/www.mdpi.com/2075-163X/ 9/9/558/s1, Figure S1: BSE images illustrating the damage of $\mathrm{K}_{2} \mathrm{CO}_{3}$-bearing samples by atmospheric humidity, Table S1: Composition ( $\mathrm{mol} \%$ ) of the run products in the $\mathrm{K}_{2} \mathrm{CO}_{3}-\mathrm{CaCO}_{3}-\mathrm{MgCO}_{3}$ ternary system at $900{ }^{\circ} \mathrm{C}$, $6 \mathrm{GPa}$ and run duration of $48 \mathrm{~h}$. (run no. D075); Table S2: Composition (mol \%) of the run products in the $\mathrm{K}_{2} \mathrm{CO}_{3}-\mathrm{CaCO}_{3}-\mathrm{MgCO}_{3}$ ternary system at $1000{ }^{\circ} \mathrm{C}, 6 \mathrm{GPa}$ and run duration of $24 \mathrm{~h}$. (run no. D077); Table S3: Composition (mol \%) of the run products in the $\mathrm{K}_{2} \mathrm{CO}_{3}-\mathrm{CaCO}_{3}-\mathrm{MgCO}_{3}$ ternary system at $1100{ }^{\circ} \mathrm{C}, 6 \mathrm{GPa}$ and run duration of $47 \mathrm{~h}$. (run no. D078); Table S4: Composition (mol \%) of the run products in the $\mathrm{K}_{2} \mathrm{CO}_{3}-\mathrm{CaCO}_{3}-\mathrm{MgCO}_{3}$ ternary system at $1100{ }^{\circ} \mathrm{C}, 6 \mathrm{GPa}$ and run duration of $6 \mathrm{~h}$. (run no. D158); Table S5: Composition (mol \%) of the run products in the $\mathrm{K}_{2} \mathrm{CO}_{3}-\mathrm{CaCO}_{3}-\mathrm{MgCO}_{3}$ ternary system at $1200{ }^{\circ} \mathrm{C}, 6 \mathrm{GPa}$ and run duration of 25 h. (run no. D079); Table S6: Composition (mol \%) of the run products in the $\mathrm{K}_{2} \mathrm{CO}_{3}-\mathrm{CaCO}_{3}-\mathrm{MgCO}_{3}$ ternary system at $1200{ }^{\circ} \mathrm{C}, 6 \mathrm{GPa}$ and run duration of $4 \mathrm{~h}$. (run no. D162); Table S7: Composition (mol \%) of the run products in the $\mathrm{K}_{2} \mathrm{CO}_{3}-\mathrm{CaCO}_{3}-\mathrm{MgCO}_{3}$ ternary system at $1200{ }^{\circ} \mathrm{C}, 6 \mathrm{GPa}$ and run duration of $10 \mathrm{~h}$. (run no. D172); Table S8: Composition (mol \%) of the run products in the $\mathrm{K}_{2} \mathrm{CO}_{3}-\mathrm{CaCO}_{3}-\mathrm{MgCO}_{3}$ ternary system at 1250 ${ }^{\circ} \mathrm{C}, 6 \mathrm{GPa}$ and run duration of $4 \mathrm{~h}$. (run no. D169); Table S9: Composition (mol \%) of the run products in the $\mathrm{K}_{2} \mathrm{CO}_{3}-\mathrm{CaCO}_{3}-\mathrm{MgCO}_{3}$ ternary system at $1300{ }^{\circ} \mathrm{C}, 6 \mathrm{GPa}$ and run duration of $2 \mathrm{~h}$. (run no. D170); Table S10: Calculation of the eutectic reactions.

Author Contributions: Conceptualization, A.S.; methodology, A.S. and K.D.L.; validation, A.S. and A.V.A.; formal analysis, A.V.A. and I.V.P.; investigation, A.V.A.; resources, K.D.L. and A.S.; data curation, A.V.A.; writing-original draft preparation, A.S. and A.V.A.; writing—review and editing, A.S.; visualization, A.V.A. and A.S.; supervision, A.S.; project administration, A.V.A. and A.S.; funding acquisition, A.S. and K.D.L.

Funding: The work is done on the state assignment of IGM SB RAS.

Acknowledgments: The SEM and EDS studies of experimental samples were performed in the Analytical Center for multi-elemental and isotope research SB RAS. We are grateful to two anonymous referees for comments that helped to improve the manuscript and N.S. Karmanov and A.T. Titov for help in analytical work.

Conflicts of Interest: The authors declare no conflict of interest. The funders had no role in the design of the study; in the collection, analyses, or interpretation of data; in the writing of the manuscript, and in the decision to publish the results.

\section{Nomenclature}

$$
\begin{array}{ll}
\mathrm{Arg}=\text { aragonite, } & \mathrm{K}_{2}=\mathrm{K}_{2} \mathrm{CO}_{3}, \\
\text { Cal = calcite, } & \mathrm{K}_{8} \mathrm{Ca}_{3}=\mathrm{K}_{8} \mathrm{Ca}_{3}\left(\mathrm{CO}_{3}\right)_{7}, \\
\text { Mg-Cal = Mg-bearing calcite, } & \left.\mathrm{K}_{2} \mathrm{Ca}=\mathrm{K}_{2} \mathrm{Ca}_{(} \mathrm{CO}_{3}\right)_{2}, \\
\text { Ca-Dol = Ca-rich dolomite, } & \mathrm{K}_{2} \mathrm{Ca}_{2}=\mathrm{K}_{2} \mathrm{Ca}_{2}\left(\mathrm{CO}_{3}\right)_{3}, \\
\text { Dol = dolomite, } & \mathrm{K}_{2} \mathrm{Ca}_{3}=\mathrm{K}_{2} \mathrm{Ca}_{3}\left(\mathrm{CO}_{3}\right)_{4}, \\
\text { Mgs = magnesite, } & \mathrm{K}_{2} \mathrm{Mg}=\mathrm{K}_{2} \mathrm{Mg}\left(\mathrm{CO}_{3}\right)_{2}, \\
\text { L = liquid, } &
\end{array}
$$

\section{References}

1. Pyle, J.M.; Haggerty, S.E. Silicate-carbonate liquid immiscibility in upper-mantle eclogites: implications for natrosilicic and carbonatitic conjugate melts. Geochim. Cosmochim. Acta 1994, 58, 2997-3011. [CrossRef]

2. Kogarko, L.N.; Henderson, C.M.B.; Pacheco, H. Primary Ca-rich carbonatite magma and carbonate-silicatesulphide liquid immiscibility in the upper mantle. Contrib. Mineral. Petrol. 1995, 121, 267-274. [CrossRef]

3. Ionov, D. Trace element composition of mantle-derived carbonates and coexisting phases in peridotite xenoliths from alkali basalts. J. Petrol. 1998, 39, 1931-1941. [CrossRef]

4. Nikolenko, E.I.; Sharygin, I.S.; Alifirova, T.A.; Korsakov, A.V.; Zelenovskiy, P.S.; Shur, V.Y. Graphite-bearing mineral assemblages in the mantle beneath Central Aldan superterrane of North Asian craton: combined confocal micro-Raman and electron microprobe characterization. J. Raman Spectrosc. 2017, 48, 1597-1605. [CrossRef]

5. Rezvukhin, D.I.; Malkovets, V.G.; Sharygin, I.S.; Tretiakova, I.G.; Griffin, W.L.; O'Reilly, S.Y. Inclusions of crichtonite-group minerals in $\mathrm{Cr}$-pyropes from the Internatsionalnaya kimberlite pipe, Siberian Craton: Crystal chemistry, parageneses and relationships to mantle metasomatism. Lithos 2018, 308, 181-195. [CrossRef]

6. Meyer, H.O.A.; McCallum, M.E. Mineral inclusions in diamonds from the Sloan kimberlites, Colorado. J. Geology 1986, 94, 600-612. [CrossRef]

7. Bulanova, G.P.; Pavlova, L.P. Magnesite peridotite assemblage in diamond from the Mir pipe. Dokl. Akad. Nauk SSSR 1987, 295, 1452-1456. 
8. Wang, A.; Pasteris, J.D.; Meyer, H.O.A.; DeleDuboi, M.L. Magnesite-bearing inclusion assemblage in natural diamond. Earth Planet. Sci. Lett. 1996, 141, 293-306. [CrossRef]

9. Stachel, T.; Harris, J.W.; Brey, G.P. Rare and unusual mineral inclusions in diamonds from Mwadui, Tanzania. Contrib. Mineral. Petrol. 1998, 132, 34-47. [CrossRef]

10. Brenker, F.E.; Vollmer, C.; Vincze, L.; Vekemans, B.; Szymanski, A.; Janssens, K.; Szaloki, I.; Nasdala, L.; Joswig, W.; Kaminsky, F. Carbonates from the lower part of transition zone or even the lower mantle. Earth Planet. Sci. Lett. 2007, 260, 1-9. [CrossRef]

11. Sobolev, N.V.; Logvinova, A.M.; Efimova, E.S. Syngenetic phlogopite inclusions in kimberlite-hosted diamonds: implications for role of volatiles in diamond formation. Russ. Geol. Geophys. 2009, 50, 1234-1248. [CrossRef]

12. Logvinova, A.M.; Wirth, R.; Zedgenizov, D.A.; Taylor, L.A. Carbonate-Silicate-Sulfide Polyphase Inclusion in Diamond from the Komsomolskaya Kimberlite Pipe, Yakutia. Geochem. Int. 2018, 56, 283-291. [CrossRef]

13. Zedgenizov, D.A.; Shatskiy, A.; Ragozin, A.L.; Kagi, H.; Shatsky, V.S. Merwinite in diamond from São Luis, Brazil: A new mineral of the Ca-rich mantle environment. Am. Mineral. 2014, 99, 547-550. [CrossRef]

14. Sobolev, N.V.; Shatsky, V.S. Diamond inclusions in garnets from metamorphic rocks: a new environment for diamond formation. Nature 1990, 343, 742-746. [CrossRef]

15. Shatsky, V.S.; Sobolev, N.V.; Vavilov, M.A. Diamond-bearing metamorphic rocks from the Kokchetav massif (Northern Kazakhstan). In Ultrahigh Pressure Metamorphism; Coleman, R.G., Wang, X., Eds.; Cambridge University Press: Cambridge, UK, 1995; pp. 427-455.

16. Dobrzhinetskaya, L.F.; Wirth, R.; Green, H.W. Nanometric inclusions of carbonates in Kokchetav diamonds from Kazakhstan: A new constraint for the depth of metamorphic diamond crystallization. Earth Planet. Sci. Lett. 2006, 243, 85-93. [CrossRef]

17. Korsakov, A.V.; Hermann, J. Silicate and carbonate melt inclusions associated with diamonds in deeply subducted carbonate rocks. Earth Planet. Sci. Lett. 2006, 241, 104-118. [CrossRef]

18. Navon, O.; Hutcheon, I.; Rossman, G.; Wasserburg, G. Mantle-derived fluids in diamond micro-inclusions. Nature 1988, 335, 784-789. [CrossRef]

19. Schrauder, M.; Navon, O. Hydrous and carbonatitic mantle fluids in fibrous diamonds from Jwaneng, Botswana. Geochim. Cosmochim. Acta 1994, 58, 761-771. [CrossRef]

20. Zedgenizov, D.A.; Ragozin, A.L.; Shatsky, V.S.; Araujo, D.; Griffin, W.L.; Kagi, H. Mg and Fe-rich carbonatesilicate high-density fluids in cuboid diamonds from the Internationalnaya kimberlite pipe (Yakutia). Lithos 2009, 112, 638-647. [CrossRef]

21. Klein-BenDavid, O.; Logvinova, A.M.; Schrauder, M.; Spetius, Z.V.; Weiss, Y.; Hauri, E.H.; Kaminsky, F.V.; Sobolev, N.V.; Navon, O. High-Mg carbonatitic micro inclusions in some Yakutian diamonds-A new type of diamond-forming fluid. Lithos 2009, 112, 648-659. [CrossRef]

22. Weiss, Y.; Kessel, R.; Griffin, W.L.; Kiflawi, I.; Klein-BenDavid, O.; Bell, D.R.; Harris, J.W.; Navon, O. A new model for the evolution of diamond-forming fluids: Evidence from microinclusion-bearing diamonds from Kankan, Guinea. Lithos 2009, 112, 660-674. [CrossRef]

23. Skuzovatov, S.; Zedgenizov, D.; Howell, D.; Griffin, W.L. Various growth environments of cloudy diamonds from the Malobotuobia kimberlite field (Siberian craton). Lithos 2016, 265, 96-107. [CrossRef]

24. Logvinova, A.M.; Wirth, R.; Tomilenko, A.A.; Afanas'ev, V.P.; Sobolev, N.V. The phase composition of crystal-fluid nanoinclusions in alluvial diamonds in the northeastern Siberian Platform. Russ. Geol. Geophys. 2011, 52, 1286-1297. [CrossRef]

25. Tomlinson, E.L.; Jones, A.P.; Harris, J.W. Co-existing fluid and silicate inclusions in mantle diamond. Earth Planet. Sci. Lett. 2006, 250, 581-595. [CrossRef]

26. Navon, O. High internal pressure in diamond fluid inclusions determined by infrared absorption. Nature 1991, 353, 746-748. [CrossRef]

27. Logvinova, A.M.; Shatskiy, A.; Wirth, R.; Ugap'eva, S.S.; Sobolev, N.V. Carbonatite melt in type Ia gem diamond. Lithos 2019, 342-343, 463-467. [CrossRef]

28. Jablon, B.M.; Navon, O. Most diamonds were created equal. Earth Planet. Sci. Lett. 2016, 443, 41-47. [CrossRef]

29. Tsuno, K.; Dasgupta, R.; Danielson, L.; Righter, K. Flux of carbonate melt from deeply subducted pelitic sediments: Geophysical and geochemical implications for the source of Central American volcanic arc. Geophys. Res. Lett. 2012, 39. [CrossRef] 
30. Grassi, D.; Schmidt, M.W. Melting of carbonated pelites at 8-13 GPa: Generating K-rich carbonatites for mantle metasomatism. Contrib. Mineral. Petrol. 2011, 162, 169-191. [CrossRef]

31. Shatskiy, A.; Arefiev, A.V.; Podborodnikov, I.V.; Litasov, K.D. Origin of K-rich diamond-forming immiscible melts and $\mathrm{CO}_{2}$ fluid via partial melting of carbonated pelites at a depth of 180-200 km. Gondwana Res. 2019, 75, 154-171. [CrossRef]

32. Litasov, K.D.; Shatskiy, A.; Ohtani, E.; Yaxley, G.M. The solidus of alkaline carbonatite in the deep mantle. Geology 2013, 41, 79-82. [CrossRef]

33. Shatskiy, A.; Litasov, K.D.; Palyanov, Y.N.; Ohtani, E. Phase relations on the $\mathrm{K}_{2} \mathrm{CO}_{3}-\mathrm{CaCO}_{3}-\mathrm{MgCO}_{3}$ join at 6 GPa and $900-1400^{\circ} \mathrm{C}$ : Implications for incipient melting in carbonated mantle domains. Am. Mineral. 2016, 101, 437-447. [CrossRef]

34. Shatskiy, A.; Litasov, K.D.; Terasaki, H.; Katsura, T.; Ohtani, E. Performance of semi-sintered ceramics as pressure-transmitting media up to $30 \mathrm{GPa}$. High Press. Res. 2010, 30, 443-450. [CrossRef]

35. Shatskiy, A.; Podborodnikov, I.V.; Arefiev, A.V.; Minin, D.A.; Chanyshev, A.D.; Litasov, K.D. Revision of the $\mathrm{CaCO}_{3}-\mathrm{MgCO}_{3}$ phase diagram at 3 and $6 \mathrm{GPa}$. Am. Mineral. 2018, 103, 441-452. [CrossRef]

36. Shatskiy, A.; Sharygin, I.S.; Gavryushkin, P.N.; Litasov, K.D.; Borzdov, Y.M.; Shcherbakova, A.V.; Higo, Y.; Funakoshi, K.-I.; Palyanov, Y.N.; Ohtani, E. The system $\mathrm{K}_{2} \mathrm{CO}_{3}-\mathrm{MgCO}_{3}$ at $6 \mathrm{GPa}$ and $900-1450{ }^{\circ} \mathrm{C}$. Am. Mineral. 2013, 98, 1593-1603. [CrossRef]

37. Arefiev, A.V.; Shatskiy, A.; Podborodnikov, I.V.; Behtenova, A.; Litasov, K.D. The system $\mathrm{K}_{2} \mathrm{CO}_{3}-\mathrm{CaCO}_{3}-$ $\mathrm{MgCO}_{3}$ at $3 \mathrm{GPa}$ : Implications for carbonatite melt compositions in the subcontinental lithospheric mantle. Minerals 2019, 9, 296. [CrossRef]

38. Shatskiy, A.; Borzdov, Y.M.; Litasov, K.D.; Sharygin, I.S.; Palyanov, Y.N.; Ohtani, E. Phase relationships in the system $\mathrm{K}_{2} \mathrm{CO}_{3}-\mathrm{CaCO}_{3}$ at $6 \mathrm{GPa}$ and $900-1450{ }^{\circ} \mathrm{C}$. Am. Mineral. 2015, 100, 223-232. [CrossRef]

39. Arefiev, A.V.; Shatskiy, A.; Podborodnikov, I.V.; Rashchenko, S.V.; Chanyshev, A.D.; Litasov, K.D. The system $\mathrm{K}_{2} \mathrm{CO}_{3}-\mathrm{CaCO}_{3}$ at $3 \mathrm{GPa}$ : Link between phase relations and variety of $\mathrm{K}-\mathrm{Ca}$ double carbonates at $\leq 0.1$ and 6 GPa. Phys. Chem. Miner. 2019, 46, 229-244. [CrossRef]

40. Arefiev, A.V.; Shatskiy, A.; Podborodnikov, I.V.; Litasov, K.D. Melting and subsolidus phase relations in the system $\mathrm{K}_{2} \mathrm{CO}_{3}-\mathrm{MgCO}_{3}$ at $3 \mathrm{GPa}$. High Press. Res. 2018, 38, 422-439. [CrossRef]

41. Cooper, A.F.; Gittins, J.; Tuttle, O.F. The system $\mathrm{Na}_{2} \mathrm{CO}_{3}-\mathrm{K}_{2} \mathrm{CO}_{3}-\mathrm{CaCO}_{3}$ at 1 kilobar and its significance in carbonatite petrogenesis. Am. J. Sci. 1975, 275, 534-560. [CrossRef]

42. Ragone, S.E.; Datta, R.K.; Roy, D.M.; Tuttle, O.F. The system potassium carbonate-magnesium carbonate. J. Phys. Chem. 1966, 70, 3360-3361. [CrossRef]

43. Arefiev, A.V.; Podborodnikov, I.V.; Shatskiy, A.F.; Litasov, K.D. Synthesis and Raman spectra of K-Ca double carbonates: $\mathrm{K}_{2} \mathrm{Ca}\left(\mathrm{CO}_{3}\right)_{2}$ bütschliite, fairchildite and $\mathrm{K}_{2} \mathrm{Ca}_{2}\left(\mathrm{CO}_{3}\right)_{3}$ at $1 \mathrm{~atm}$. Geochem. Int. 2019, 57, 981-987. [CrossRef]

44. Podborodnikov, I.V.; Shatskiy, A.; Arefiev, A.V.; Bekhtenova, A.; Litasov, K.D. New data on the system $\mathrm{Na}_{2} \mathrm{CO}_{3}-\mathrm{CaCO}_{3}-\mathrm{MgCO}_{3}$ at $6 \mathrm{GPa}$ with implications to the composition and stability of carbonatite melts at the base of continental lithosphere. Chem. Geol. 2019, 515, 50-60. [CrossRef]

45. Podborodnikov, I.V.; Shatskiy, A.; Arefiev, A.V.; Litasov, K.D. Phase relations in the system $\mathrm{Na}_{2} \mathrm{CO}_{3}-\mathrm{CaCO}_{3}-$ $\mathrm{MgCO}_{3}$ at $3 \mathrm{GPa}$ with implications for carbonatite genesis and evolution. Lithos 2019, 330-331, 74-89. [CrossRef]

46. Eitel, W.; Skaliks, W. Ueber einige doppelcarbonate der alkalien und erdalkalien. Z. Anorg. Allg. Chem. 1929, 183, 263-286. [CrossRef]

47. Brey, G.P.; Bulatov, V.K.; Girnis, A.V. Melting of K-rich carbonated peridotite at 6-10 GPa and the stability of K-phases in the upper mantle. Chem. Geol. 2011, 281, 333-342. [CrossRef]

48. Pabst, A. Synthesis, properties, and structure of $\mathrm{K}_{2} \mathrm{Ca}\left(\mathrm{CO}_{3}\right)_{2}$, buetschliite. Am. Mineral. 1974, 59, 353-358.

49. Hesse, K.-F.; Simons, B. Crystalstructure of synthetic $\mathrm{K}_{2} \mathrm{Mg}\left(\mathrm{CO}_{3}\right)_{2}$. Z. Krist. 1982, 161, 289-292. [CrossRef]

50. Golubkova, A.; Merlini, M.; Schmidt, M.W. Crystal structure, high-pressure, and high-temperature behavior of carbonates in the $\mathrm{K}_{2} \mathrm{Mg}\left(\mathrm{CO}_{3}\right)_{2}-\mathrm{Na}_{2} \mathrm{Mg}\left(\mathrm{CO}_{3}\right)_{2}$ join. Am. Mineral. 2015, 100, 2458-2467. [CrossRef]

51. Logvinova, A.; Zedgenizov, D.; Wirth, R. Specific Multiphase assemblages of carbonatitic and Al-rich silicic diamond-forming fluids/melts: TEM observation of micro inclusions in cuboid diamonds from the placers of northeastern Siberian Craton. Minerals 2019, 9, 50. [CrossRef]

52. Stachel, T.; Harris, J.W.; Brey, G.P.; Joswig, W. Kankan diamonds (Guinea) II: Lower mantle inclusion parageneses. Contrib. Mineral. Petrol. 2000, 140, 16-27. [CrossRef] 
53. Kaminsky, F.; Wirth, R.; Matsyuk, S.; Schreiber, A.; Thomas, R. Nyerereite and nahcolite inclusions in diamond: Evidence for lower-mantle carbonatitic magmas. Mineral. Mag. 2009, 73, 797-816. [CrossRef]

54. Smith, E.M.; Kopylova, M.G.; Dubrovinsky, L.; Navon, O.; Ryder, J.; Tomlinson, E.L. Transmission X-ray diffraction as a new tool for diamond fluid inclusion studies. Mineral. Mag. 2011, 75, 2657-2675. [CrossRef]

55. Kaminsky, F.V.; Wirth, R.; Schreiber, A. Carbonatitic inclusions in deep mantle diamond from Juina, Brazil: New minerals in the carbonate-halide association. Can. Mineral. 2013, 51, 669-688. [CrossRef]

56. Stachel, T.; Luth, R.W. Diamond formation-Where, when and how? Lithos 2015, 220, 200-220. [CrossRef]

57. Pal'yanov, Y.N.; Sokol, A.G.; Borzdov, Y.M.; Khokhryakov, A.F.; Sobolev, N.V. Diamond formation from mantle carbonate fluids. Nature 1999, 400, 417-418. [CrossRef]

58. Palyanov, Y.N.; Bataleva, Y.V.; Sokol, A.G.; Borzdov, Y.M.; Kupriyanov, I.N.; Reutsky, V.N.; Sobolev, N.V. Mantle-slab interaction and redox mechanism of diamond formation. Proc. Natl. Acad. Sci. USA 2013, 110, 20408-20413. [CrossRef]

59. Girnis, A.V.; Brey, G.P.; Bulatov, V.K.; Höfer, H.E.; Woodland, A.B. Graphite to diamond transformation during sediment-peridotite interaction at 7.5 and $10.5 \mathrm{GPa}$. Lithos 2018, 310, 302-313. [CrossRef]

60. Wang, Y.; Kanda, H. Growth of HPHT diamonds in alkali halides: possible effects of oxygen contamination. Diam. Relat. Mater. 1998, 7, 57-63. [CrossRef]

61. Arima, M.; Nakayama, K.; Akaishi, M.; Yamaoka, S.; Kanda, H. Crystallization of diamond from a silicate melt of kimberlite composition in high-pressure and high-temperature experiments. Geology 1993, 21, 968-970. [CrossRef]

62. Akaishi, M. New nonmetallic catalysts for the synthesis of high-pressure, high-temperature diamond. Diam. Relat. Mater. 1993, 2, 183-189. [CrossRef]

63. Palyanov, Y.N.; Sokol, A.G. The effect of composition of mantle fluids/melts on diamond formation processes. Lithos 2009, 112, 690-700. [CrossRef]

64. Katsura, T.; Yoneda, A.; Yamazaki, D.; Yoshino, T.; Ito, E. Adiabatic temperature profile in the mantle. Phys. Earth Planet. Inter. 2010, 183, 212-218. [CrossRef]

65. Kennedy, C.S.; Kennedy, G.C. The equilibrium boundary between graphite and diamond. J. Geophys. Res. 1976, 81, 2467-2470. [CrossRef]

66. Shatskiy, A.; Litasov, K.D.; Sharygin, I.S.; Ohtani, E. Composition of primary kimberlite melt in a garnet lherzolite mantle source: Constraints from melting phase relations in anhydrous Udachnaya-East kimberlite with variable $\mathrm{CO}_{2}$ content at $6.5 \mathrm{GPa}$. Gondwana Res. 2017, 45, 208-227. [CrossRef]

67. Kavanagh, J.L.; Sparks, R.S.J. Temperature changes in ascending kimberlite magma. Earth Planet. Sci. Lett. 2009, 286, 404-413. [CrossRef]

68. Pollack, H.N.; Chapman, D.S. On the regional variation of heat flow, geotherms, and lithospheric thickness. Tectonophysics 1977, 38, 279-296. [CrossRef]

69. Zedgenizov, D.A.; Logvinova, A.M.; Shatskii, V.S.; Sobolev, N.V. Inclusions in microdiamonds from some kimberlite diatremes of Yakutia. Dokl. Earth Sci. 1998, 359, 204-208.

70. Klein-BenDavid, O.; Izraeli, E.S.; Hauri, E.; Navon, O. Mantle fluid evolution-A tale of one diamond. Lithos 2004, 77, 243-253. [CrossRef]

71. Klein-BenDavid, O.; Wirth, R.; Navon, O. TEM imaging and analysis of micro inclusions in diamonds: A close look at diamond-growing fluids. Am. Mineral. 2006, 91, 353-365. [CrossRef]

72. Klein-BenDavid, O.; Izraeli, E.S.; Hauri, E.; Navon, O. Fluid inclusions in diamonds from the Diavik mine, Canada and the evolution of diamond-forming fluids. Geochim. Cosmochim. Acta 2007, 71, 723-744. [CrossRef]

73. Zedgenizov, D.A.; Rege, S.; Griffin, W.L.; Kagi, H.; Shatsky, V.S. Composition of trapped fluids in cuboid fibrous diamonds from the Udachnaya kimberlite: LAM-ICPMS analysis. Chem. Geol. 2007, 240, 151-162. [CrossRef]

74. Skuzovatov, S.Y.; Zedgenizov, D.A.; Shatsky, V.S.; Ragozin, A.L.; Kuper, K.E. Composition of cloudy micro inclusions in octahedral diamonds from the Internatsional'naya kimberlite pipe (Yakutia). Russ. Geol. Geophys. 2011, 52, 85-96. [CrossRef]

75. Zedgenizov, D.A.; Ragozin, A.L.; Shatsky, V.S.; Araujo, D.; Griffin, W.L. Fibrous diamonds from the placers of the northeastern Siberian Platform: carbonate and silicate crystallization media. Russ. Geol. Geophys. 2011, 52, 1298-1309. [CrossRef]

76. Smith, E.M.; Kopylova, M.G.; Nowell, G.M.; Pearson, D.G.; Ryder, J. Archean mantle fluids preserved in fibrous diamonds from Wawa, Superior craton. Geology 2012, 40, 1071-1074. [CrossRef] 
77. Weiss, Y.; Kiflawi, I.; Davies, N.; Navon, O. High-density fluids and the growth of monocrystalline diamonds. Geochim. Cosmochim. Acta 2014, 141, 145-159. [CrossRef]

78. Shatskiy, A.; Borzdov, Y.M.; Litasov, K.D.; Kupriyanov, I.N.; Ohtani, E.; Palyanov, Y.N. Phase relations in the system $\mathrm{FeCO}_{3}-\mathrm{CaCO}_{3}$ at $6 \mathrm{GPa}$ and $900-1700{ }^{\circ} \mathrm{C}$ and its relation to the system $\mathrm{CaCO}_{3}-\mathrm{FeCO}_{3}-\mathrm{MgCO}_{3}$. Am. Mineral. 2014, 99, 773-785. [CrossRef]

79. Shatskiy, A.; Litasov, K.D.; Ohtani, E.; Borzdov, Y.M.; Khmelnicov, A.I.; Palyanov, Y.N. Phase relations in the $\mathrm{K}_{2} \mathrm{CO}_{3}-\mathrm{FeCO}_{3}$ and $\mathrm{MgCO}_{3}-\mathrm{FeCO}_{3}$ systems at $6 \mathrm{GPa}$ and $900-1700{ }^{\circ} \mathrm{C}$. Eur. J. Mineral. 2015, 27, 487-499. [CrossRef]

80. Tychkov, N.S.; Agashev, A.M.; Malygina, E.V.; Nikolenko, E.I.; Pokhilenko, N.P. Thermal perturbations in the lithospheric mantle as evidenced from PT equilibrium conditions of xenoliths from the Udachnaya kimberlite pipe. Dokl. Earth Sci. 2014, 454, 84-88. [CrossRef]

81. Agashev, A.M.; Pokhilenko, L.N.; Pokhilenko, N.P.; Shchukina, E.V. Geochemistry of eclogite xenoliths from the Udachnaya Kimberlite Pipe: Section of ancient oceanic crust sampled. Lithos 2018, 314-315, 187-200. [CrossRef]

82. Boyd, F.R.; Nixon, P.H. Origins of the ultramafic nodules from some kimberlites of northern Lesotho and the Monastery Mine, South Africa. Phys. Chem. Earth 1975, 9, 431-454. [CrossRef]

83. Green, H.W.; Gueguen, Y. Origin of kimberlite pipes by diapiric upwelling in the upper mantle. Nature 1974, 249, 617-620. [CrossRef]

84. Agashev, A.M.; Pokhilenko, N.R.; Takazawa, E.; McDonald, J.A.; Vavilov, M.A.; Watanabe, I.; Sobolev, N.V. Primary melting sequence of a deep $(>250 \mathrm{~km})$ lithospheric mantle as recorded in the geochemistry of kimberlite-carbonatite assemblages, Snap Lake dyke system, Canada. Chem. Geol. 2008, 255, 317-328. [CrossRef]

85. Yaxley, G.M.; Brey, G.P. Phase relations of carbonate-bearing eclogite assemblages from 2.5 to 5.5 GPa: Implications for petrogenesis of carbonatites. Contrib. Mineral. Petrol. 2004, 146, 606-619. [CrossRef]

86. Dasgupta, R.; Hirschmann, M.M. Effect of variable carbonate concentration on the solidus of mantle peridotite. Am. Mineral. 2007, 92, 370-379. [CrossRef]

87. Brey, G.P.; Bulatov, V.K.; Girnis, A.V.; Lahaye, Y. Experimental melting of carbonated peridotite at 6-10 GPa. J. Petrol. 2008, 49, 797-821. [CrossRef]

(C) 2019 by the authors. Licensee MDPI, Basel, Switzerland. This article is an open access article distributed under the terms and conditions of the Creative Commons Attribution (CC BY) license (http://creativecommons.org/licenses/by/4.0/). 